Prepared in cooperation with the Arkansas Natural Resources Commission

\title{
Groundwater-Flow Assessment of the Mississippi River Valley Alluvial Aquifer of Northeastern Arkansas
}

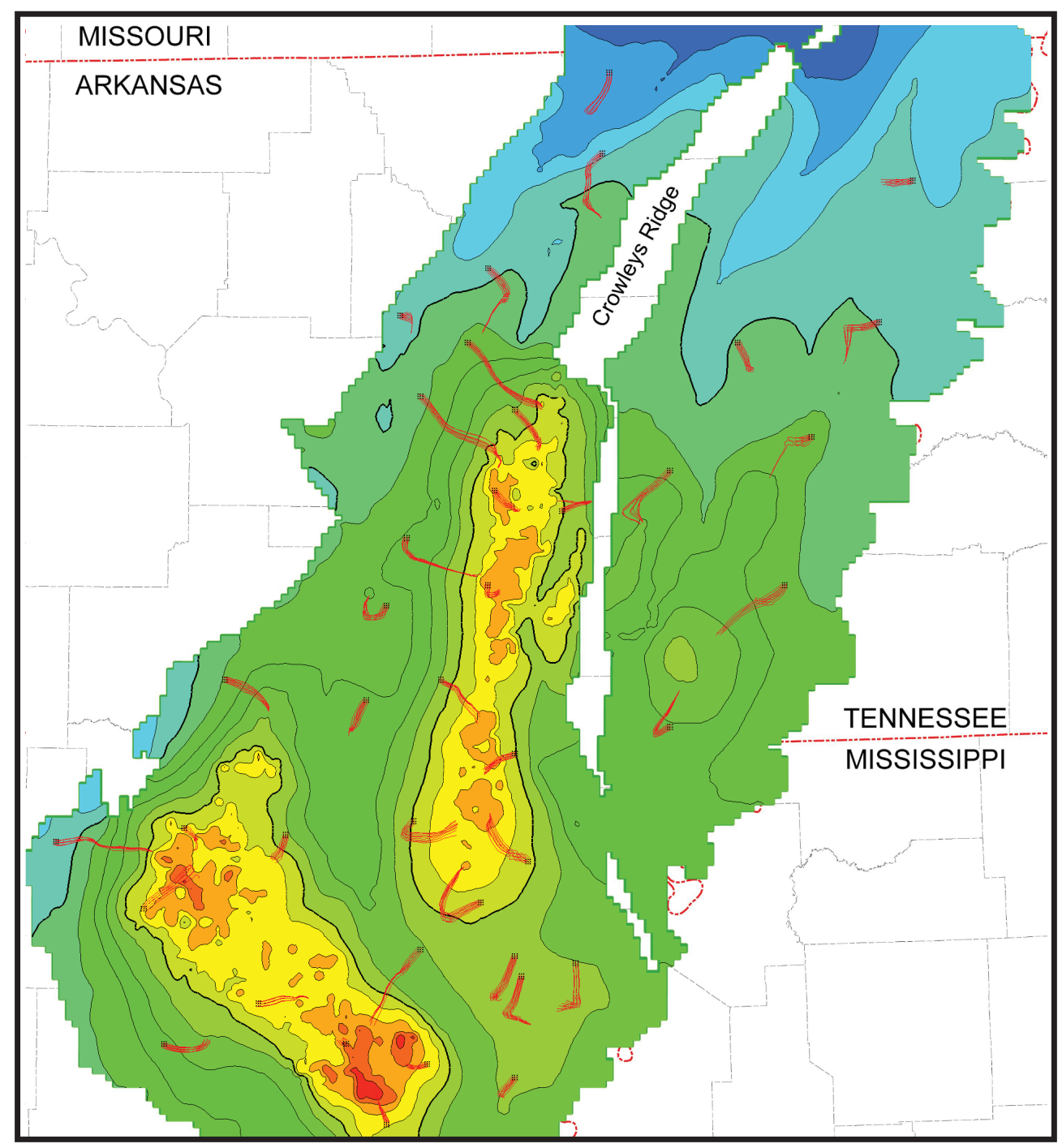

Scientific Investigations Report 2010-5210 


\section{Groundwater-Flow Assessment of the Mississippi River Valley Alluvial Aquifer of Northeastern Arkansas}

By John B. Czarnecki

Prepared in cooperation with the Arkansas Natural Resources Commission

Scientific Investigations Report 2010-5210 


\section{U.S. Department of the Interior \\ KEN SALAZAR, Secretary \\ U.S. Geological Survey \\ Marcia K. McNutt, Director}

U.S. Geological Survey, Reston, Virginia: 2010

This and other USGS information products are available at http://store.usgs.gov/
U.S. Geological Survey
Box 25286 , Denver Federal Center
Denver, CO 80225
To learn about the USGS and its information products visit http://www.usgs.gov/
1-888-ASK-USGS

Any use of trade, product, or firm names is for descriptive purposes only and does not imply endorsement by the U.S. Government.

Although this report is in the public domain, permission must be secured from the individual copyright owners to reproduce any copyrighted materials contained within this report.

Suggested citation:

Czarnecki, J.B., 2010, Groundwater-flow assessment of the Mississippi River Valley alluvial aquifer of northeastern Arkansas: U.S. Geological Survey Scientific Investigations Report 2010-5210, 33 p. 


\section{Contents}

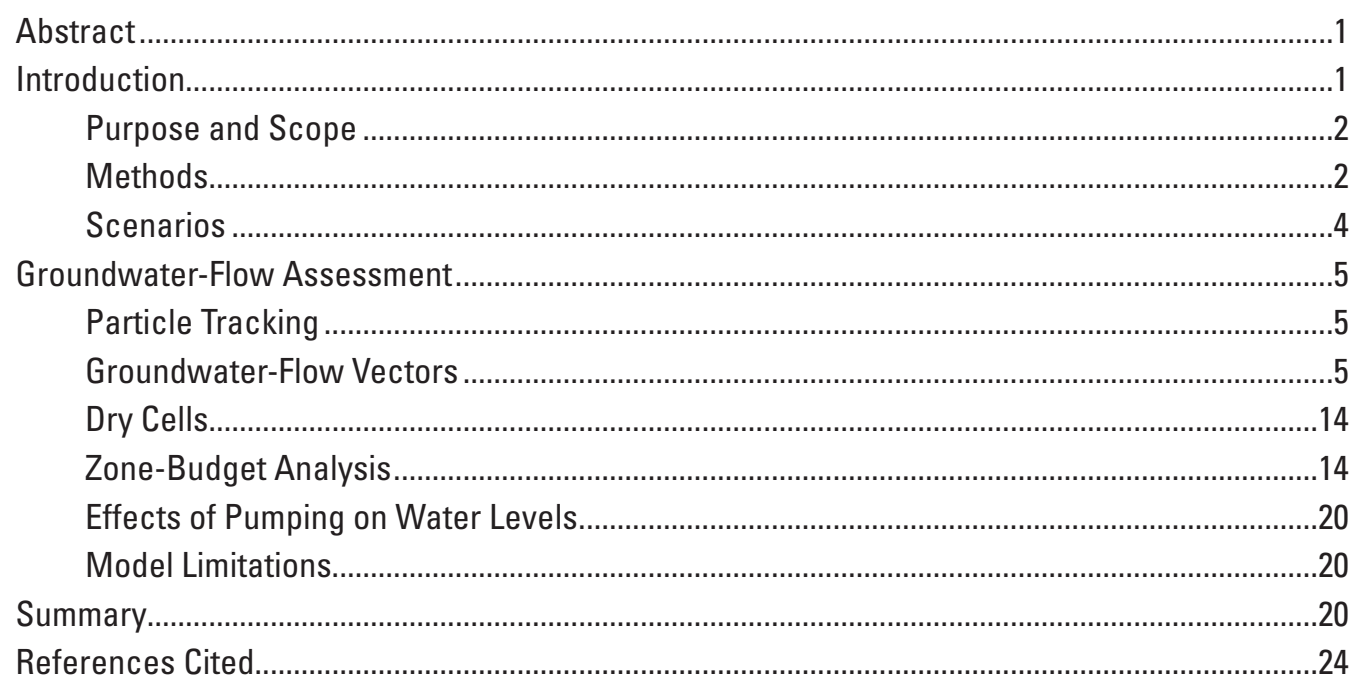

\section{Figures}

1. Map showing location of model area.............................................................................

2. Graph showing difference in simulated hydraulic head between stand-alone MODFLOW and Groundwater Modeling System for stress period beginning in 2005, scenario 1

3-18. Maps showing:

3. Forward particle tracks from 1918 to 2050 and simulated hydraulic head

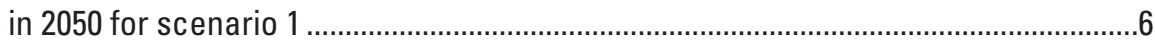

4. Forward particle tracks from 1918 to 2050 and simulated hydraulic head

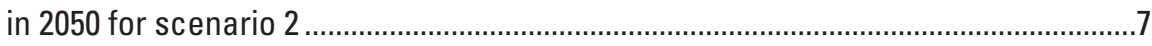

5. Backward particle tracks from 2050 to 1918 and simulated hydraulic head in 2050 for scenario 1 ......................................................................................

6. Backward particle tracks from 2050 to 1918 and simulated hydraulic head

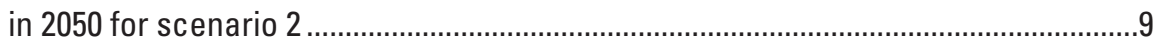

7. Vectors of groundwater flow and hydraulic head on January 1, 2010, for scenario 1

8. Vectors of groundwater flow and hydraulic head on January 1, 2050, for scenario 1

9. Vectors of groundwater flow and hydraulic head on Janary 1, 2010, for scenario 2

10. Vectors of groundwater flow and hydraulic head on January 1, 2050, for scenario 2

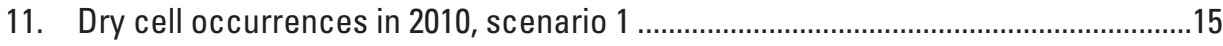

12. Dry cell occurrences in 2050, scenario 1 .............................................................16

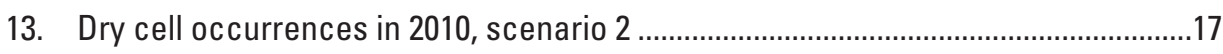




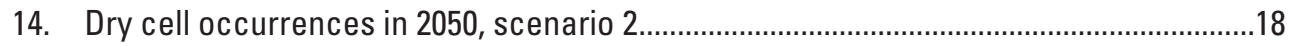

15. Model area divided into four zones used in zone-budget analysis .................................19

16. Simulated water levels from scenario 2 minus water levels from scenario 1 ..................21

17. Simulated water levels from scenario 3 minus water levels from scenario 1 ..................22

18. Simulated water levels from scenario 2 minus water levels from scenario 3 .................23

\section{Tables}

1. Flow budget for zone $\mathbf{1}$ (northwestern section of the model) for 2010 and 2050 for

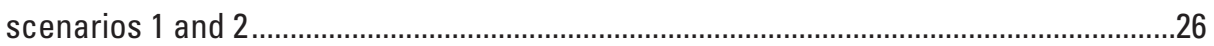

2. Flow budget for zone 2 (Cache Critical Groundwater Area) for 2010 and 2050 for

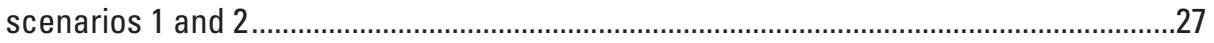

3. Flow budget for zone 3 (section of the model from Crowleys Ridge eastward) for

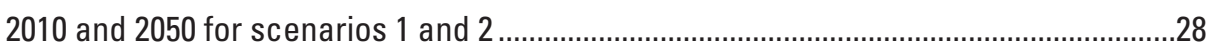

4. Flow budget for zone 4 (southern section of the model) for 2010 and 2050 for

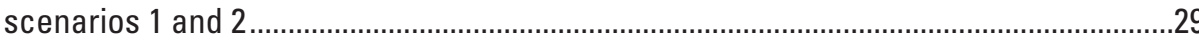

5. Flow budget for zone 1 (northwestern section of the model) for 2010 and 2050

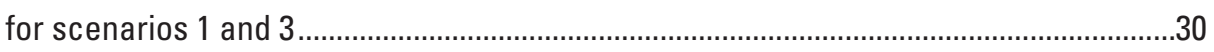

6. Flow budget for zone 2 (Cache Critical Groundwater Area) for 2010 and 2050 for

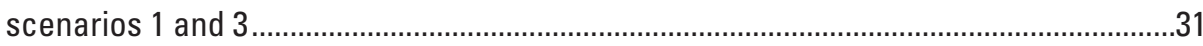

7. Flow budget for zone 3 (section of the model from Crowleys Ridge eastward) for

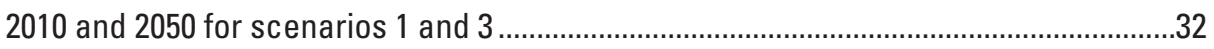

8. Flow budget for zone 4 (southern section of the model) for 2010 and 2050 for scenarios 1 and 3 


\section{Conversion Factors}

\begin{tabular}{|c|c|c|}
\hline Multiply & By & To obtain \\
\hline \multicolumn{3}{|c|}{ Length } \\
\hline mile (mi) & 1.609 & kilometer (km) \\
\hline foot $(\mathrm{ft})$ & 0.3048 & meter $(\mathrm{m})$ \\
\hline \multicolumn{3}{|c|}{ Area } \\
\hline square mile $\left(\mathrm{mi}^{2}\right)$ & 2.590 & square kilometer $\left(\mathrm{km}^{2}\right)$ \\
\hline \multicolumn{3}{|c|}{ Volume } \\
\hline cubic meter $\left(\mathrm{m}^{3}\right)$ & 0.0008107 & acre-foot (acre-ft) \\
\hline \multicolumn{3}{|c|}{ Flow rate } \\
\hline acre-foot per day (acre-ft/d) & 0.01427 & cubic meter per second $\left(\mathrm{m}^{3} / \mathrm{s}\right)$ \\
\hline acre-foot per year (acre-ft/yr) & 1,233 & cubic meter per year $\left(\mathrm{m}^{3} / \mathrm{yr}\right)$ \\
\hline foot per day (ft/d) & 0.3048 & meter per day $(\mathrm{m} / \mathrm{d})$ \\
\hline foot per year (ft/yr) & 0.3048 & meter per year $(\mathrm{m} / \mathrm{yr})$ \\
\hline cubic foot per day $\left(\mathrm{ft}^{3} / \mathrm{d}\right)$ & 0.02832 & cubic meter per day $\left(\mathrm{m}^{3} / \mathrm{d}\right)$ \\
\hline gallon per minuter (gal/min) & 0.06309 & liter per second (L/s) \\
\hline gallon per day (gal/d) & 0.003785 & cubic meter per day $\left(\mathrm{m}^{3} / \mathrm{d}\right)$ \\
\hline million gallons per day (Mgal/d) & 0.04381 & cubic meter per second $\left(\mathrm{m}^{3} / \mathrm{s}\right)$ \\
\hline
\end{tabular}

Altitude, as used in this report, refers to distance above the vertical datum, and is referenced to the National Geodetic Vertical Datum of 1929 (NGVD of 1929).

Latitude and longitude are referenced to the North American Datum of 1983 (NAD of 1983). 


\title{
Groundwater-Flow Assessment of the Mississippi River Valley Alluvial Aquifer of Northeastern Arkansas
}

\author{
By John B. Czarnecki
}

\section{Abstract}

The Mississippi River Valley alluvial aquifer is a waterbearing assemblage of gravels and sands that underlies about 32,000 square miles of Arkansas, Kentucky, Louisiana, Mississippi, Missouri, and Tennessee. Pumping of groundwater from the alluvial aquifer for agriculture started in the early 1900s in the Grand Prairie area for the irrigation of rice and soybeans. From 1965 to 2005, water use in the alluvial aquifer increased 655 percent. In 2005, 6,242 million gallons per day of water were pumped from the aquifer, primarily for irrigation and fish farming. Water-level declines in the alluvial aquifer were documented as early as 1927 . Long-term water-level measurements in the alluvial aquifer show an average annual decline of 1 foot per year in some areas.

In this report, the utility of the updated 2009 MODFLOW groundwater-flow model of the alluvial aquifer in northeastern Arkansas was extended by performing groundwater-flow assessments of the alluvial aquifer at specific areas of interest using a variety of methods. One such area is along the western side of Crowleys Ridge, which includes western parts of Clay, Greene, Craighead, Poinsett, Cross, St. Francis, and Lee Counties. This area was designated as the Cache Critical Groundwater Area by the Arkansas Natural Resources Commission in 2009 for the alluvial and Sparta/Memphis aquifers, because of the rate of change in groundwater levels and groundwater levels have dropped below half the original saturated thickness of the alluvial aquifer.

Three scenarios were simulated, in part, to allow assessment of the role that pumping in Jackson and Woodruff Counties has on water levels and flow rates into and out of the cone of depression located along the western side of Crowleys Ridge. In scenario 1 (the baseline scenario), the 2005 pumping rate is applied from 2005 through 2050 without change. In scenario 2, pumping is the same as in scenario 1 except that the pumping rate in Jefferson and Woodruff Counties is specified as zero from 1998 to 2050 . In scenario 3, pumping is the same as in scenario 1 except that the pumping rate in Jefferson and Woodruff Counties is specified as half the rate specified for stress periods from 1998 to 2050.

Particle tracking using MODPATH was done to assess the direction and time of travel that particles take from specific model locations. Factors that affect how far particles will travel include: (1) pumping rates in the vicinity of particles, (2) when and if model cells with pumping wells go dry, and (3) changes in pumping rates during the simulation period. Particles can travel further if cells do not go dry and pumping in a model cell can continue even if the total pumping rate from the model is specified with a lesser rate. Particles introduced in Jackson and Woodruff Counties travel somewhat further for scenario 2 than for scenario 1.

Flow vectors were generated using the built-in graphics capability in the Groundwater Modeling System. Groundwater-flow vectors depict both magnitude and direction of simulated groundwater flow. Groundwater-flow magnitude is the product of the hydraulic gradient and hydraulic conductivity. Only two values of hydraulic conductivity (230 and 730 feet per day) are specified over the model domain. Variability in groundwater-flow magnitude is caused largely by variation in hydraulic gradient. Groundwater-flow vectors and hydraulic-head maps for scenarios 1 and 2 for the beginning of 2010 and the beginning of 2050 were generated to allow for a comparison of flow rates and direction. The lengths of the vectors presented represent the horizontal magnitude of flow, and the orientation of each vector indicates the horizontal direction of flow.

Zone-budget analyses using ZONEBUDGET were performed to assess the rate of water entering and leaving specified zones within the model. Zone-budget analysis was performed on the simulated groundwater flow by dividing the model into four separate zones and calculating the individual flow components for each zone at different simulation times for the three pumping scenarios. Reduction of pumping in scenarios 2 and 3 resulted in substantially more groundwater flow into the counties east of Jackson and Woodruff Counties, and more flow to rivers within the model area.

\section{Introduction}

The Mississippi River Valley alluvial aquifer (hereafter referred to as the alluvial aquifer) is a water-bearing assemblage of gravels and sands that underlies about 32,000 square miles $\left(\mathrm{mi}^{2}\right)$ of Arkansas, Kentucky, Louisiana, Mississippi, 
Missouri, and Tennessee. In Arkansas, the alluvial aquifer occurs in an area generally ranging from 50 to 125 miles (mi) in east to west extent and about 250 mi north to south, adjacent to the Mississippi River (Holland, 2007). Pumping of groundwater from the alluvial aquifer in Arkansas for agriculture started in the early 1900s in the Grand Prairie area for the irrigation of rice and soybeans. From 1965 to 2005, water use in the alluvial aquifer in Arkansas increased 655 percent. In 2005, 6,242 million gallons per day (Mgal/d) of water were pumped from the aquifer in the area of this study (fig. 1), primarily for irrigation and fish farming (Gillip and Czarnecki, 2009). Water-level declines in the alluvial aquifer were documented as early as 1927 (Engler and others, 1945). Long-term water-level measurements in the alluvial aquifer show an average annual decline of 1 foot per year in some areas (Schrader, 2006).

A MODFLOW-2000 digital groundwater-flow model of the alluvial aquifer of northeastern Arkansas (Reed, 2003) was developed to assist groundwater managers with assessing the effect of future stresses on the groundwater-flow system induced by groundwater pumping. Reed's (2003) model was updated to include water-use and water-level data from 1998 to 2005 as part of model validation (Gillip and Czarnecki, 2009). The model area (fig. 1) covers $14,104 \mathrm{mi}^{2}$, and includes all or part of 23 counties in Arkansas and all or part of 5 counties in Missouri.

In a study conducted by the U.S. Geological Survey, in cooperation with the Arkansas Natural Resources Commission, the utility of the model of Gillip and Czarnecki (2009) (hereafter referred to as the updated model) was extended by performing groundwater-flow assessments of the alluvial aquifer at specific areas of interest using a variety of methods. One such area is along the western side of Crowleys Ridge (fig. 1), which includes western parts of Clay, Greene, Craighead, Poinsett, Cross, St. Francis, and Lee Counties. This area was designated as the Cache Critical Groundwater Area (CCGWA) by the Arkansas Natural Resources Commission in 2009 for both the alluvial and Sparta/Memphis aquifers, because groundwater levels have dropped below half the original saturated thickness of the alluvial aquifer.

\section{Purpose and Scope}

The purpose of this report is to describe a groundwaterflow assessment of the Mississippi River Valley alluvial aquifer by documenting various analyses of groundwater flow using the updated version of the Gillip and Czarnecki (2009) groundwater-flow model that was adapted to the Groundwater Modeling System (GMS) platform (Aquaveo, 2009). Groundwater flow within the model area was assessed using particle tracking, groundwater-flow vectors, and zone-budget analyses. Three different pumping scenarios were analyzed for the simulation period of 1918 to 2050 . A comparison of dry-cell distribution for two of the scenarios is presented.
This report highlights the usefulness of using groundwater-flow models to better understand the dynamics of the groundwater-flow system of the alluvial aquifer in areas of interest. Increasing or decreasing groundwater pumping in one area may have a substantial effect on the movement of groundwater and associated water-level variations. To illustrate the effect that decreasing groundwater pumping in an area has on groundwater flow within the alluvial aquifer, this report discusses the effect of setting pumping rates in Jackson and Woodruff Counties to zero. Jackson and Woodruff Counties were selected because of their location just to the west of the CCGWA, which has developed a cone of depression west of Crowleys Ridge. Conceptually, much of the groundwater recharge to this cone of depression flows from Jackson and Woodruff Counties. In 2005, Jackson County pumped 383 $\mathrm{Mgal} / \mathrm{d}$ and Woodruff County pumped $266 \mathrm{Mgal} / \mathrm{d}$, the sum of both representing about 10 percent of the $6,242 \mathrm{Mgal} / \mathrm{d}$ total groundwater withdrawals in the model area (Holland, 2007).

\section{Methods}

The updated model MODFLOW files were imported into the GMS software package (Aquaveo, 2009), which uses a modified version of MODFLOW. GMS incorporates particletracking, zone-budget analyses and groundwater flow-vector plotting through the use of U.S. Geological Survey (USGS) MODPATH (Pollock, 1994), ZONEBUDGET (Harbaugh, 1990), and built-in vector plotting software. Importing the model MODFLOW files into GMS was made possible through the file/import feature within GMS. However, some file structure and input specifications were modified for compatibility between these software applications. GMS also computes vertical leakage corrections differently than the stand-alone MODFLOW version. To assess these potential effects, a comparison of model output between the GMS version and the stand-alone MODFLOW version was performed by taking the difference in simulated hydraulic head values at all model cells at various time steps. In general, the comparison was good, as illustrated by the preponderance of difference values grouped between $+/-0.5 \mathrm{ft}$ (fig. 2) for scenario 1 (see Scenarios section), which is typical of the other stress periods in the model. This comparison indicates that the GMS version of the model calculates similar results to the stand-alone MODFLOW version. The period of simulation was from the beginning of 1918 (predevelopment, steady state) to 2050.

Particle tracking using MODPATH was done to assess the direction and distance of travel that particles take from specific model locations. Initial locations of particles were selected to provide an overall assessment of particle paths throughout the model area and to highlight particle movement in areas of interest. Particles were introduced at several points within the model area and their paths tracked forward and backward from their initial locations. Particle tracks were plotted showing the location and time of arrival of the particles using animation, which included the simulation time of the particle-tracking image. 


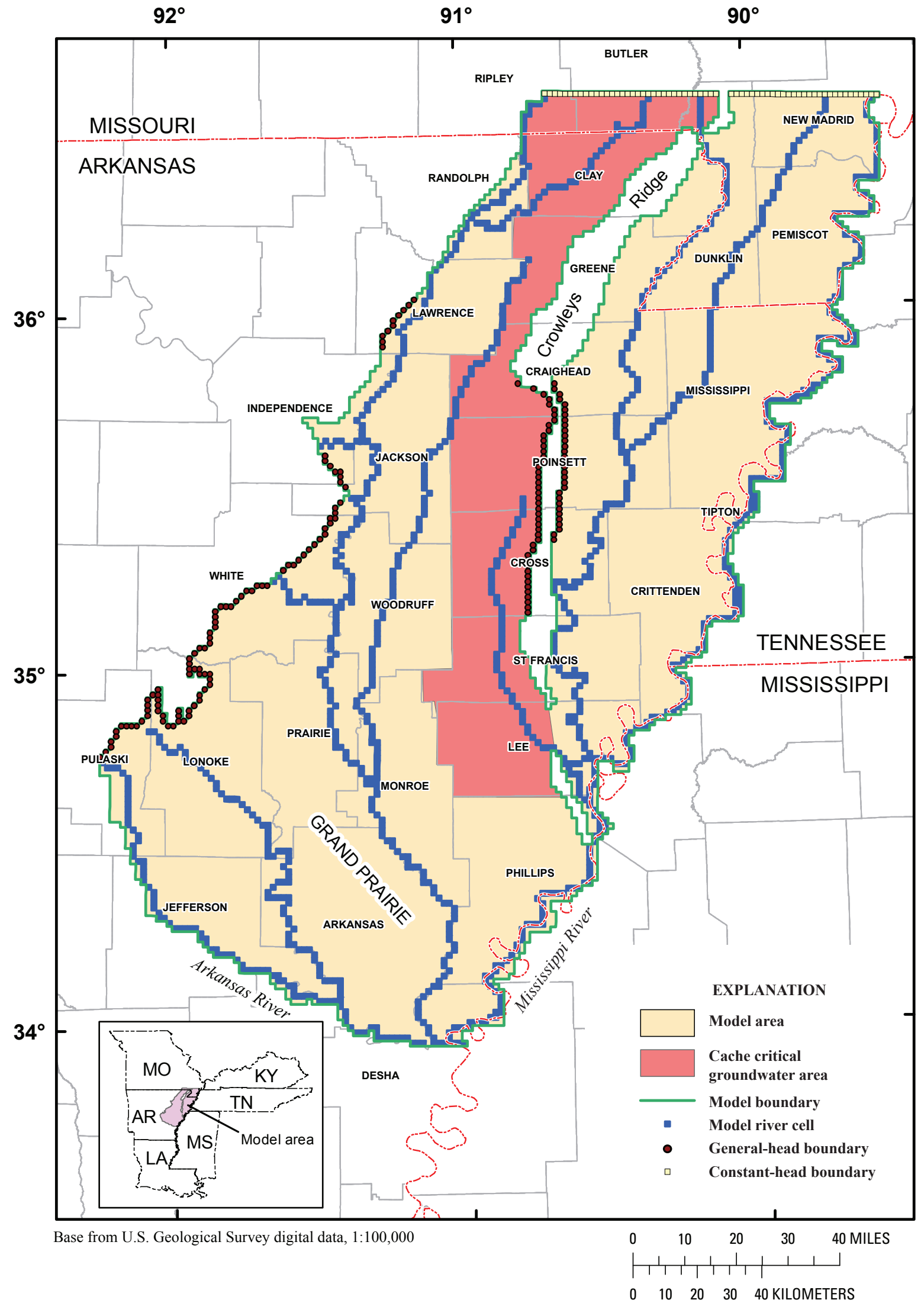

Figure 1. Location of model area. 


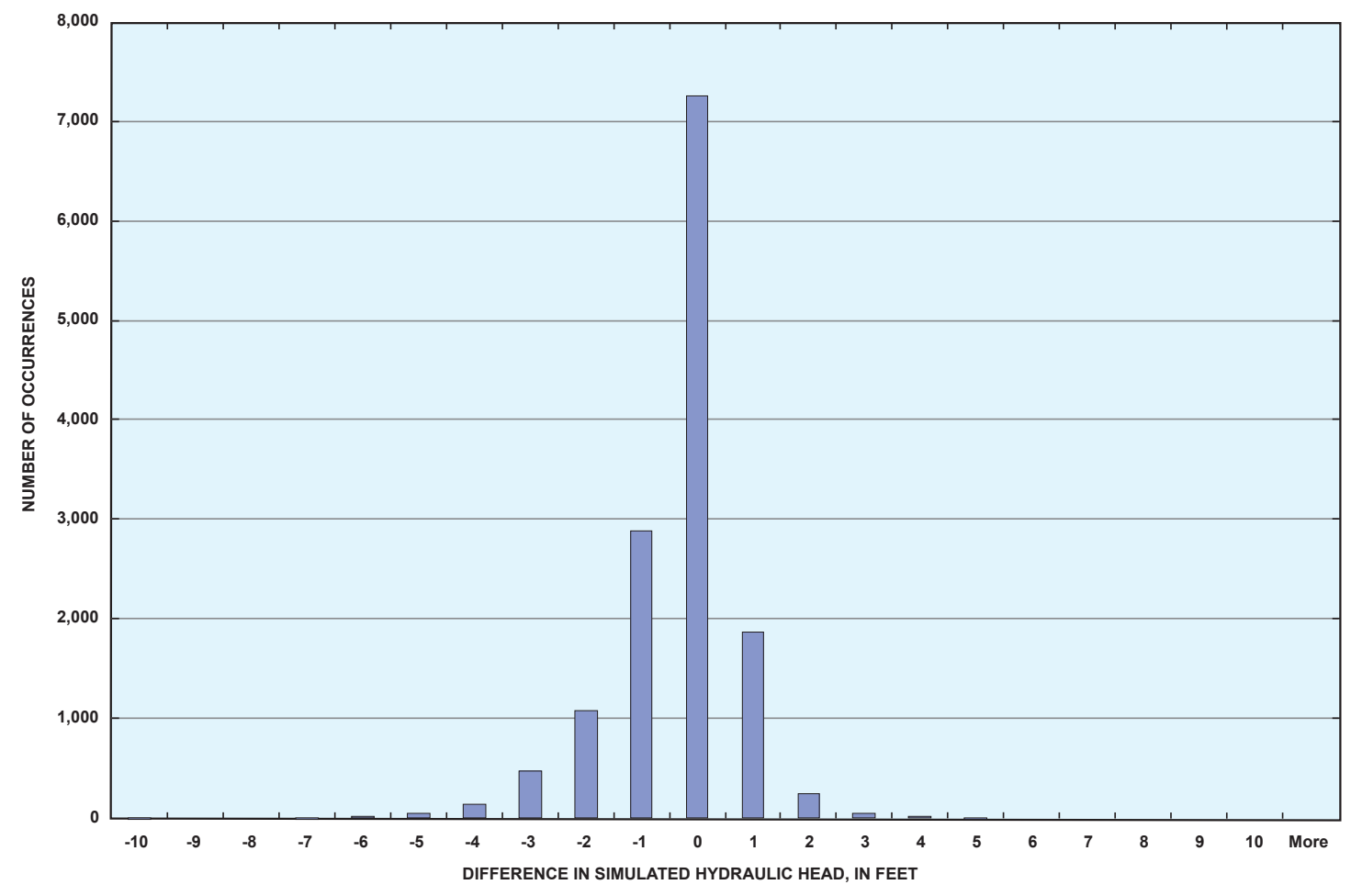

Figure 2. Difference in simulated hydraulic head between stand-alone MODFLOW and Groundwater Modeling System for stress period beginning in 2005, scenario 1.

Flow vectors were generated using the built-in graphics capability in GMS. Plots of flow vectors were generated to show the direction and magnitude of groundwater flow over the entire model area for different periods and pumping conditions.

Zone-budget analyses using ZONEBUDGET were performed to assess the rate of water entering and leaving specified zones within the model. A zone assemblage of four zones was constructed that included a separate zone comprising parts of counties located west of Crowleys Ridge, known as the CCGWA (Arkansas Natural Resources Commission, 2009). For this set of zones, because of the interest in assessing the effect of external pumping on Craighead and Poinsett Counties, zone-budget analyses were done with full pumping and no pumping from Jackson and Woodruff Counties for the period 1998 to 2050. Differences in groundwater-flow rates were calculated by subtracting the values obtained from each zone for scenarios 1 and 2 and for scenarios 1 and 3 . An additional set of zone-budget analyses was done with full pumping and half pumping from Jackson and Woodruff Counties for the period 1998 to 2050. Flow into and out of each zone is represented by various flow components, which may or may not be present in a zone depending on the zone's location in the model. Except for flow out of wells and areally distributed recharge, flow can be either into or out of the following flow components in a zone: storage (either water stored in pore space or water released as the aquifer matrix compresses); constant heads (this is a line of cells on the north side of the model area whose hydraulic head is maintained at a specified altitude, the flow from which is proportional to the gradient between the constant-head cell and the adjacent model cell to the south); general-head boundaries (this is similar to a constant-head cell, but the flow from or to it is proportional to the hydraulic gradient and a conductance term assigned to the cell); and river cells.

\section{Scenarios}

Three hypothetical scenarios were simulated, in part, to allow assessment of the role that pumping in Jackson and Woodruff Counties has on groundwater levels and flow rates into and out of counties located along the western side of Crowleys Ridge. The scenarios are as follows:

- In scenario 1 (the baseline scenario), the 2005 pumping rate is applied from 2005 through 2050 without change (full pumping); pumping rates prior to 2005 are variable.

- In scenario 2, pumping is the same as in scenario 1 except that the pumping rate in Jackson and Woodruff Counties is specified as zero from 1998 to 2050.

- In scenario 3, pumping is the same as in scenario 1 except that the pumping rate in Jackson and Woodruff Counties is specified as 50 percent (half pumping) of the rate specified for stress periods from 1998 to 2050 .

Hypothetical scenarios involving reductions in pumping in Jackson and Woodruff Counties are not intended to imply that such reductions are likely or even possible. The reductions in pumping were simulated primarily to evaluate the effect that pumping has on other parts of the flow system. 


\section{Groundwater-Flow Assessment}

The following sections discuss four different analyses of the model results. These analyses comprise: (1) particle tracking, (2) groundwater-flow vector comparison, (3) drycell assessment, and (4) zone-budget analyses. Each of these analyses provides a means to compare the effect of varying pumping within the model for different pumping scenarios.

\section{Particle Tracking}

Particle tracking was performed using the version of MODPATH (Pollock, 1994), included as part of the GMS software package (Aquaveo, 2009). Particles were introduced at model cell locations shown on figures 3-6. To achieve the particle tracking, a porosity value of 0.20 was assigned uniformly thoughout the model domain. Particle positions were computed by MODPATH at multiple locations in the model domain and tracked forward from the beginning of the first model stress period (1918) to the end of simulation in 2050 and backward beginning in 2050 to the first stress period of the simulation using scenario 1 (the baseline scenario) and scenario 2. Particle tracking results using scenario 3 are not presented in this report because they did not show appreciable differences with scenario 2. Particles are allowed to pass through weak sinks, such as rivers or general-head boundaries. Graphical results also are contained within the audio video interleave (avi) file that accompanies this report. The animation shows updated particle positions every 10 years along with updated hydraulic head values going from 1928 to 2050 for scenario 1.

Factors that affect the distance particles will travel include: (1) pumping rates in the vicinity of particles, (2) when and if pumping cells go dry, and (3) changes in pumping rates during the simulation period. Particles can travel further if cells do not go dry and can continue to pump even if the total pumping rate from the model may be less. Particles introduced in Jackson and Woodruff Counties travel further for scenario 2 than for scenario 1. As pumping is turned off in Jackson and Woodruff Counties, water levels rise causing an increase in the local hydraulic gradient to the east, which results in particles moving faster and farther in that direction (fig. 4). Some forward particle tracks appear to make abrupt turns (figs. 3 and 4), particularly in Monroe County. This phenomenon occurs when pumping from one location is overwhelmed by pumping occurring later in time at a different location, causing particles to be deflected toward that larger pumping center.

In the southern part of the model area, particles in Arkansas County are drawn toward the center of the relatively large cone of depression occurring there. Particles that start near the center of the large cones travel a shorter distance because the hydraulic gradient is less than it is toward the margins of the cone of depression, and the starting position of particles are closer to strong sinks where particle movement ends.

Backward particle tracking (figs. 5 and 6) results in shorter particle track lengths compared to forward particle tracking (figs. 3 and 4). This occurs because the overall hydraulic gradients are smaller earlier in the simulation.

\section{Groundwater-Flow Vectors}

Groundwater-flow vectors depict both magnitude and direction of simulated groundwater flow. Groundwater-flow magnitude is the product of the hydraulic gradient and hydraulic conductivity. Only two values of hydraulic conductivity (230 and 730 feet per day (ft/d)) are specified over the model domain; the $230 \mathrm{ft} / \mathrm{d}$ value is specified in the southern part of the model area in Arkansas, Lonoke, and Prairie Counties. Variability in groundwater-flow magnitude is caused largely by variation in hydraulic gradient.

Groundwater-flow vectors and hydraulic-head maps for scenarios 1 and 2 for 2010 and 2050 were generated (figs. 7-10) to allow for a comparison of groundwater-flow magnitude and direction. The lengths of the vectors presented in figures 7-10 represent the horizontal magnitude of flow, and the orientation of each vector indicates the horizontal direction of flow. Vectors have a vertical component of flow as well, but that component is not depicted in these figures. To avoid crowding on the vector diagrams, a flow vector for every eleventh model cell was used in the construction of these figures. The tail of each vector occurs at the center of its corresponding model cell where the flow is calculated. For scenario 1, flow-vector magnitudes (represented by the apparent length of each vector) are largest on the western side of the cone of depression located west of Crowleys Ridge (figs. 7-8). This indicates that there is a large component of flow that originates from the west and moves toward the cone of depression west of Crowley Ridge. The very small vectors in the center of the cone of depression in the southern part of the model area (Arkansas, Prairie, and Lonoke Counties) result, in part, because of the presence of dry cells in which pumping stops once they become dry. If the water level in a cell drops to within $10 \mathrm{ft}$ of the bottom of a model cell, the cell is considered dry and that cell becomes inactive from that point in time to the end of the simulation. The southern part of the model area also has the smaller value of hydraulic conductivity (230 $\mathrm{ft} / \mathrm{d}$ ) used in the model.

When pumping from Jackson and Woodruff Counties is set to zero (scenario 2), the larger hydraulic gradient that occurs between those two counties and counties to the east causes flow magnitudes to be larger. This increase can be seen by comparing figures 7 and 9 and 8 and 10 . The largest change in flow magnitude occurs in eastern Jackson County and western Poinsett County, although the direction of flow is largely similar with flow occurring mostly toward the east. 


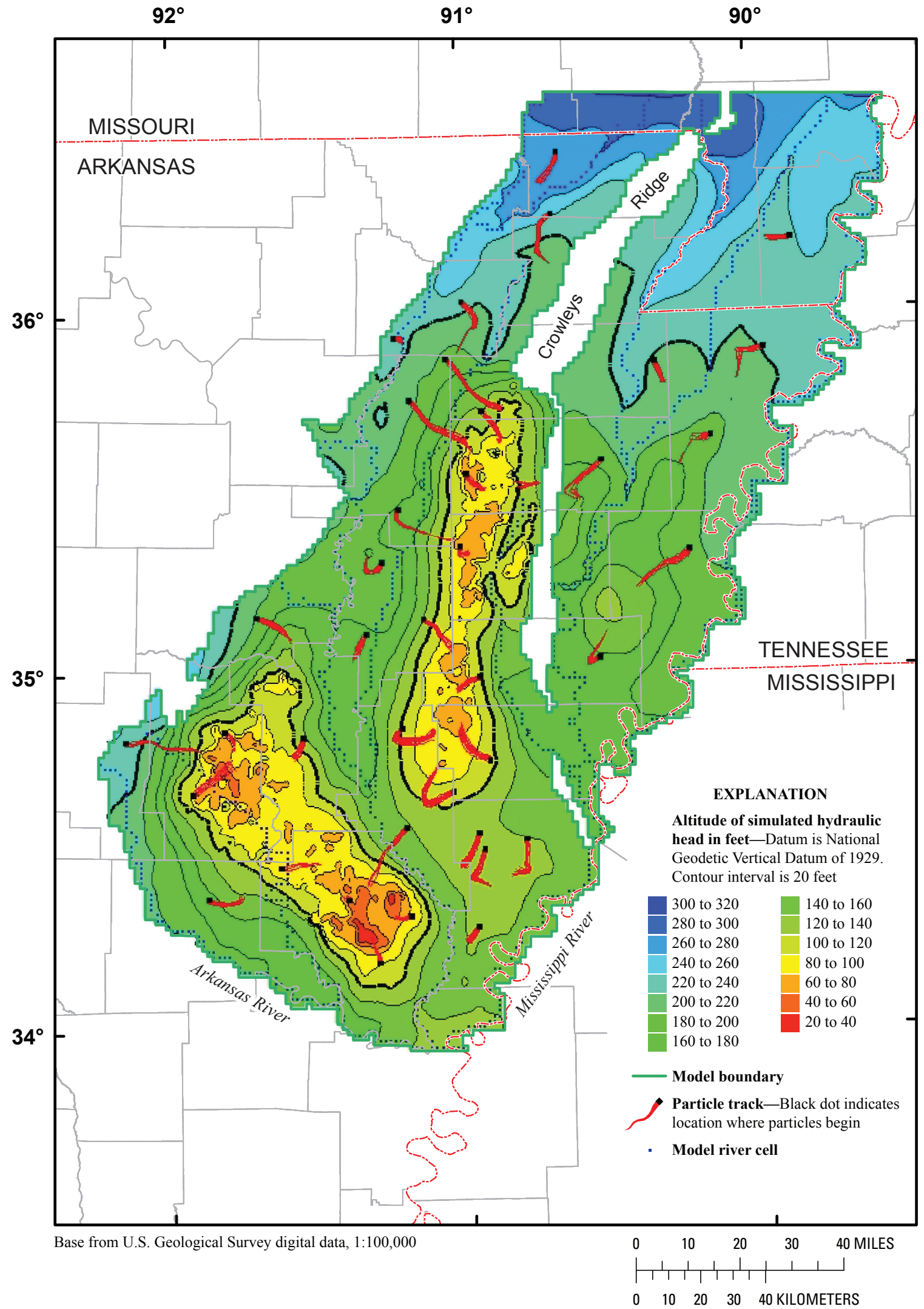

Figure 3. Forward particle tracks from 1918 to 2050 and simulated hydraulic head in 2050 for scenario 1. 


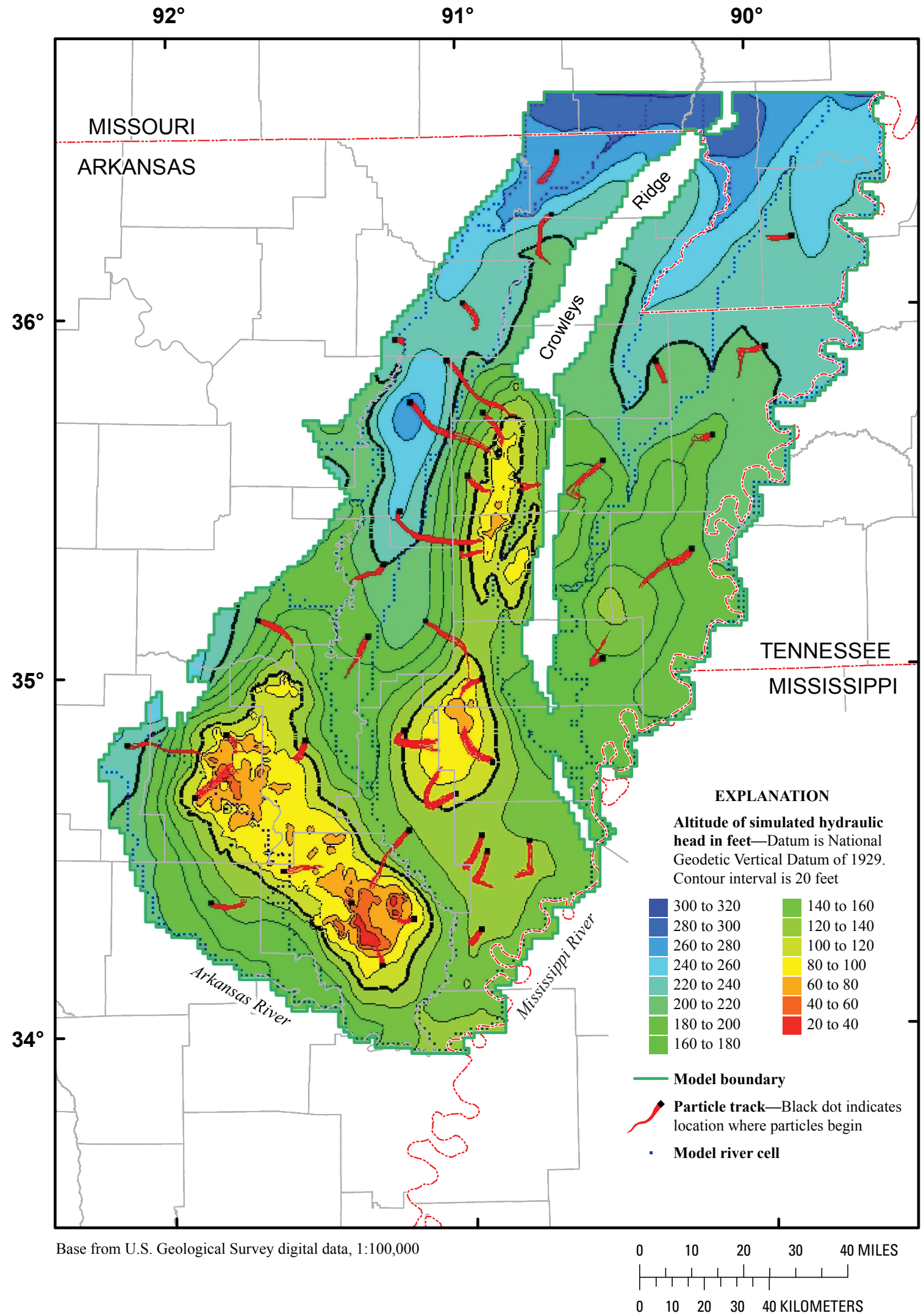

Figure 4. Forward particle tracks from 1918 to 2050 and simulated hydraulic head in 2050 for scenario 2 . 


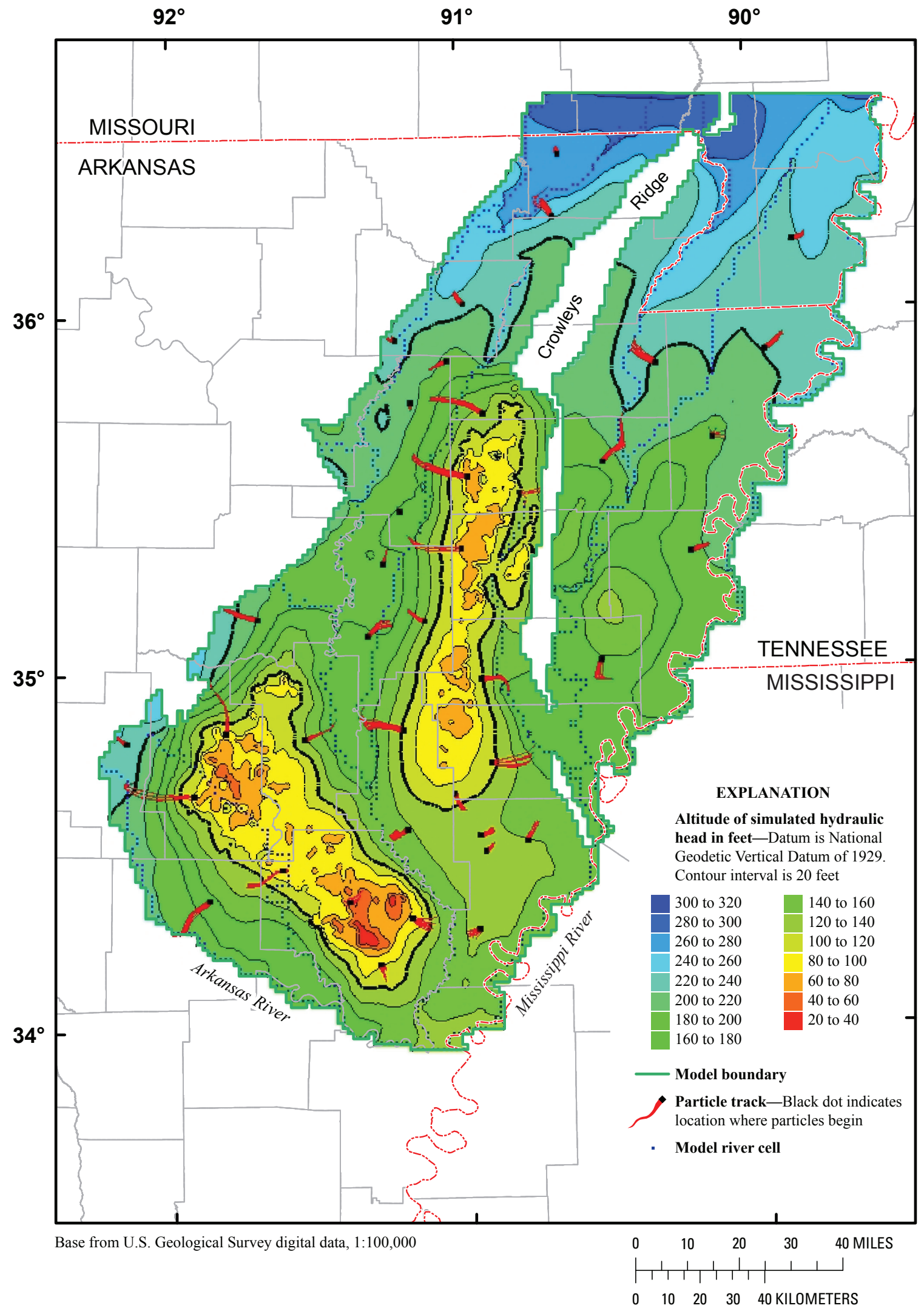

Figure 5. Backward particle tracks from 2050 to 1918 and simulated hydraulic head in 2050 for scenario 1. 


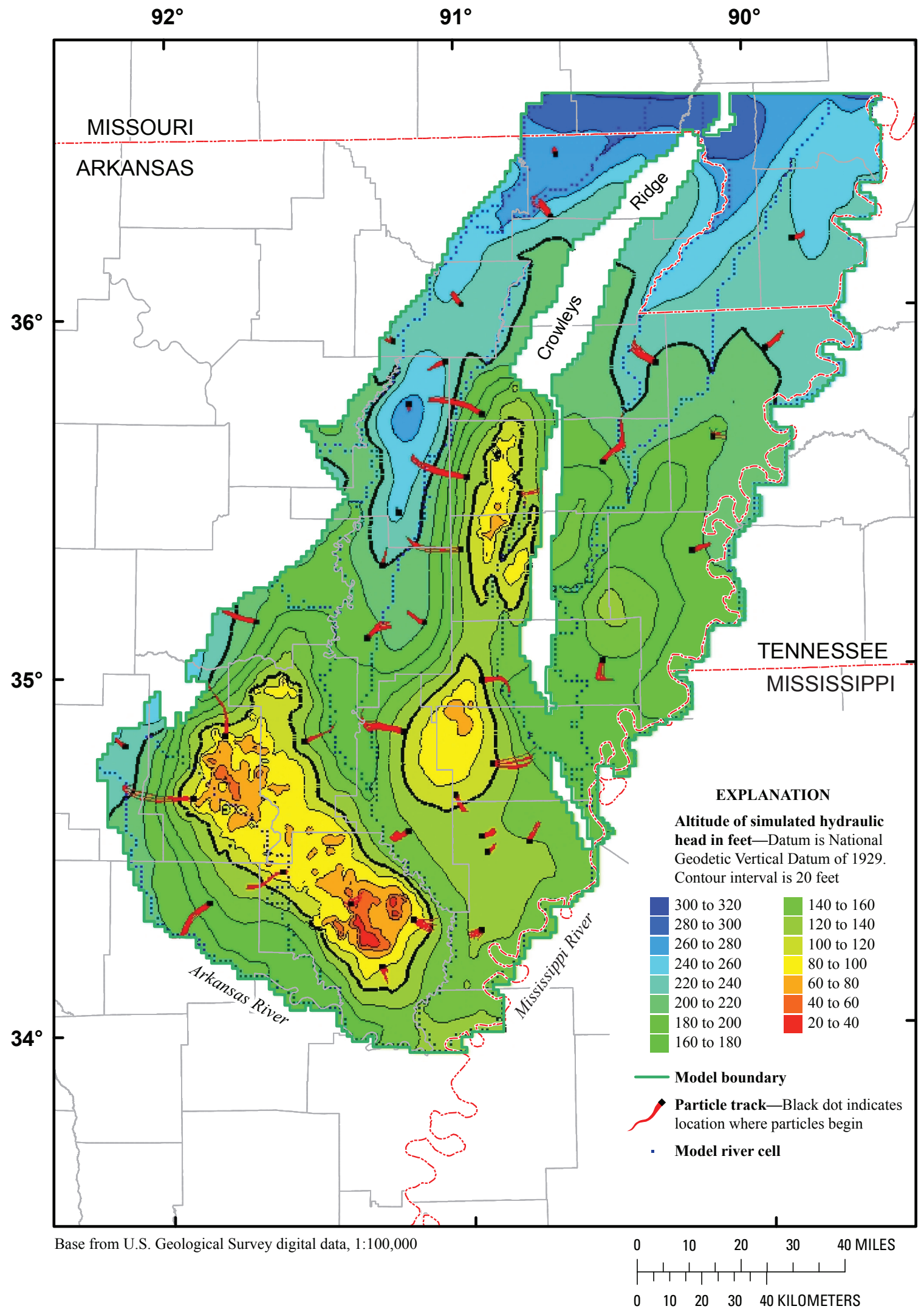

Figure 6. Backward particle tracks from 2050 to 1918 and simulated hydraulic head in in 2050 for scenario 2. 


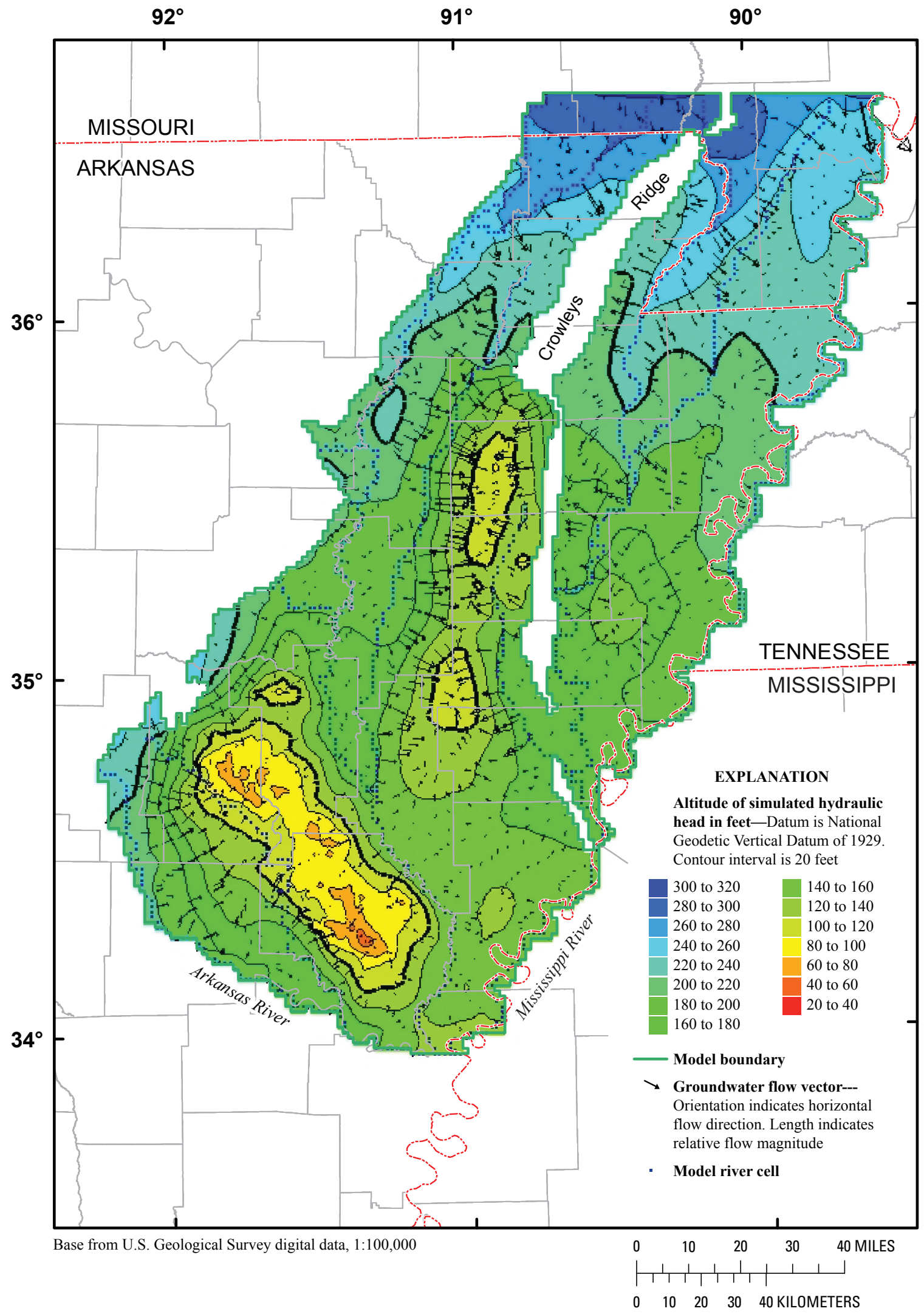

Figure 7. Vectors of groundwater flow and hydraulic head on January 1, 2010, for scenario 1. 


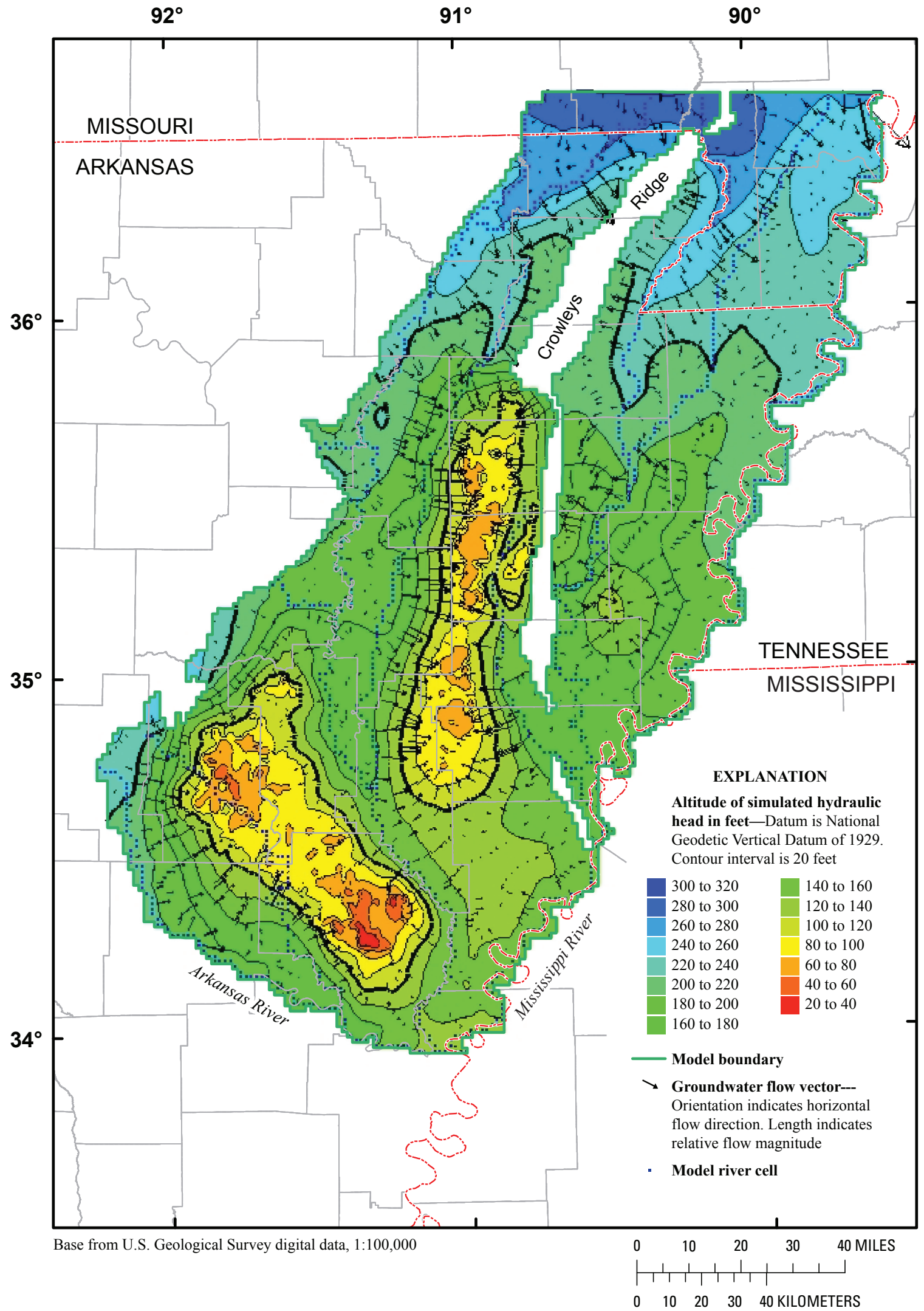

Figure 8. Vectors of groundwater flow and hydraulic head on January 1, 2050, for scenario 1. 


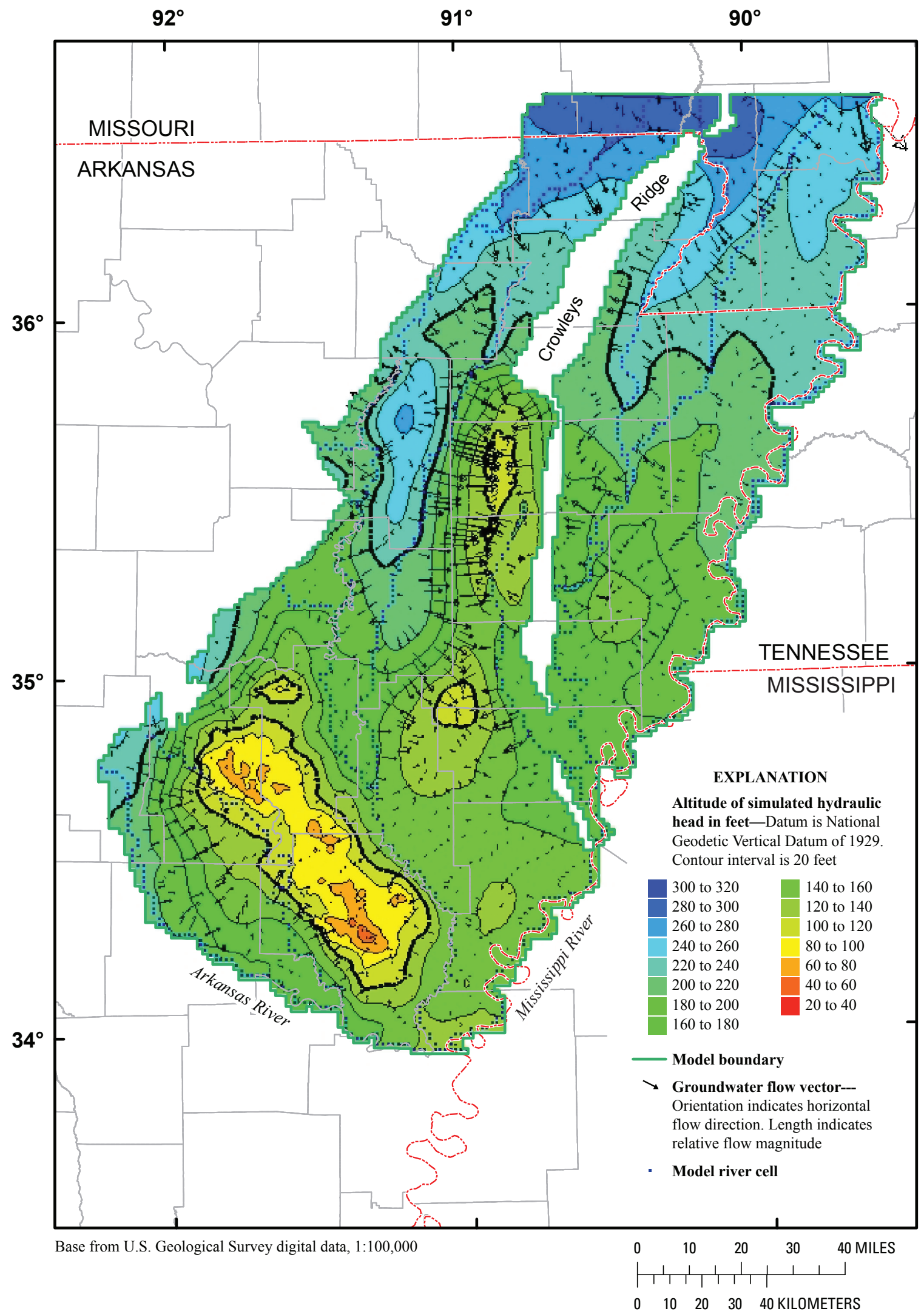

Figure 9. Vectors of groundwater flow and hydraulic head on January 1, 2010, for scenario 2. 


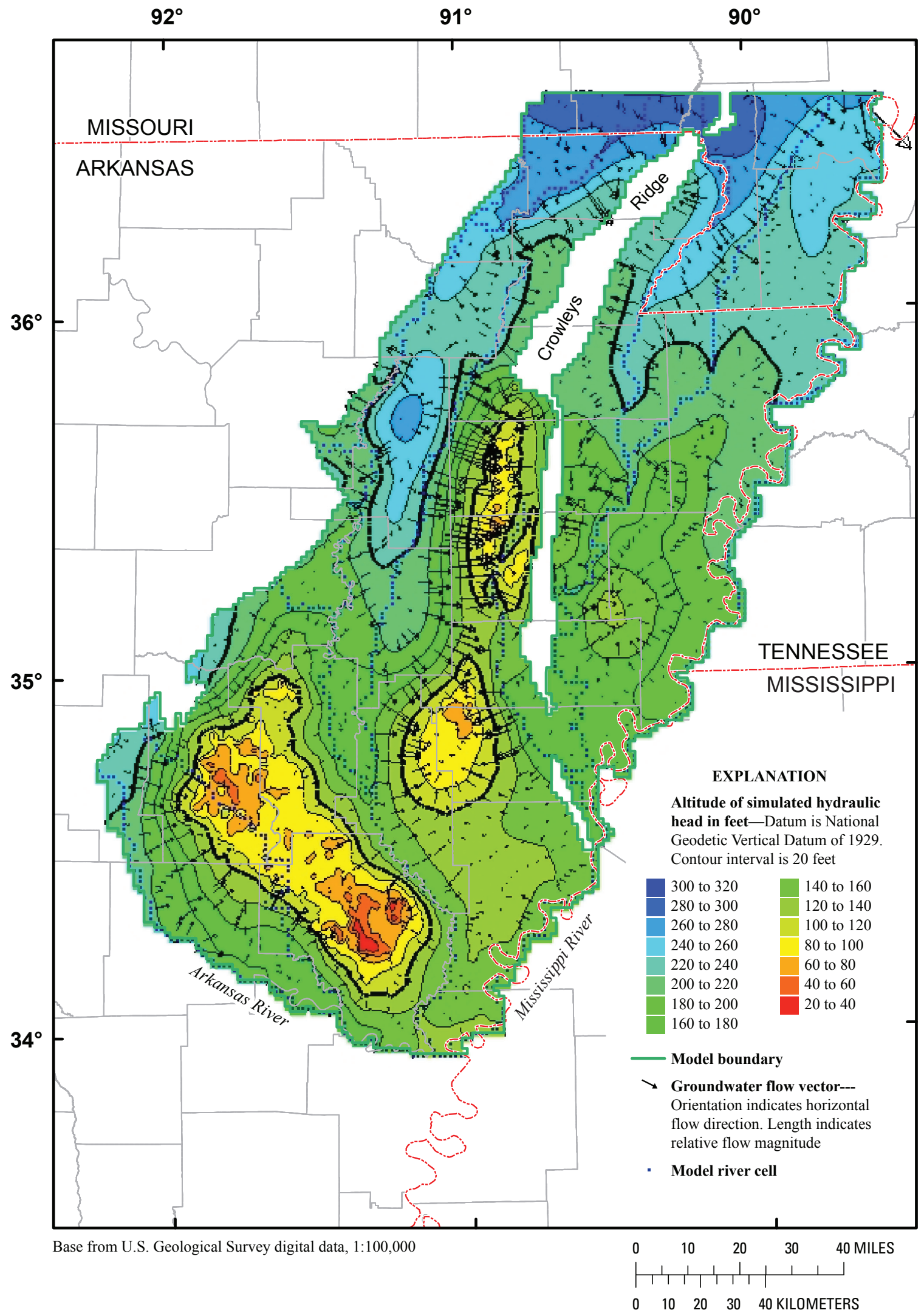

Figure 10. Vectors of groundwater flow and hydraulic head on January 1, 2050, for scenario 2. 


\section{Dry Cells}

If the simulated water level within a model cell drops to within $10 \mathrm{ft}$ of the altitude of the bottom of the model cell, the cell is considered dry and becomes inactive until the end of the simulation. If pumping occurs in a cell and the cell goes dry during the simulation, then pumping ceases in that cell and remains off throughout the remaining simulation period. The occurrence and distribution of dry cells varies between model stress periods and scenarios.

Evidence of the change in number of dry cells with time can be seen by comparing their occurrence in 2010 and 2050 for each of the two scenarios presented. For scenario 1,78 dry cells occur at the beginning of 2010 (fig. 11) compared to 671 at the beginning of 2050 (fig. 12). When pumping in Jackson and Woodruff Counties is specified as zero (scenario 2), 78 dry cells occur at the beginning of 2010 (fig. 13) and 476 at the beginning of 2050 (fig. 14). This indicates that with a relatively small reduction in total pumpage of 10 percent, the number of simulated dry cells in the model area decreases by about 29 percent.

\section{Zone-Budget Analysis}

Zone-budget analysis was performed on the simulated groundwater flow by dividing the model into four separate zones (fig. 15) and calculating the individual flow components for each zone at different simulation times. Zone 1 (fig. 15) includes all or part of Randolph, Lawrence, Independence, Jackson, White, and Woodruff Counties. Zone 2 includes the CCGWA, which comprises the western parts of counties that are divided by Crowleys Ridge. These counties include Clay, Greene, Craighead, Poinsett, Cross, St. Francis, and Lee. Zone 3 is the part of the model area east of Crowleys Ridge. Zone 4 represents all or part of the seven southernmost counties in the model area.

Flow components were obtained from the model for 2010 and 2050. Flow components and their percentage relative to the total flow in the zone of interest are listed in tables 1-8 (at end of report). Fractional percentages (absolute values less than 1) are not shown in these tables.

Zone-budget analysis allows the user to identify where the largest flow components into and out of each zone occur, helping to provide an understanding of the overall dynamics of the flow system. In addition, by using the same zones for different scenarios, a quantitative comparison may be made to see how flow rates for each of the flow components differ given different pumping rates at specific times during a model simulation.

Most of the flow into zone 1 is from areally distributed recharge, which ranges from 71 to 86 percent, and from rivers, which ranges from 8 to 16 percent (table 1). Flow out of zone 1 occurs largely from pumping from wells, which was 80 to 84 percent of the total flow in 2010 and 2050. Specifying a pumping rate of zero in Jackson and Woodruff Counties results in a reduction of flow out from wells in zone 1 of 49 and 51 percent in 2010 and 2050, respectively, and an increase in discharge to rivers of 19 and 23 percent. Flow from zone 1 to zone 2 (located along the eastern side of zone 1) increased by 11 to 16 percent in 2010 and 2050 when a pumping rate of zero in Jackson and Woodruff Counties was specified. No flow is reported between zones 1 and 3 because these two zones are not connected. Flow between zones 1 and 4 was minor, representing 4 percent or less of the total.

Flow into zone 2 (fig. 15; table 2), or the CCGWA, occurs from multiple sources, with the largest component of flow occurring as areally distributed recharge, which ranges from 37 to 43 percent depending on the simulation period. Flow into zone 2 from recharge from rivers ranges from 20 to 34 percent resulting from induced flow toward cones of depression caused by pumping from wells. Lateral flow from zone 1 to zone 2 ranges from 7 to 18 percent depending on the simulation period and pumping rates in Jackson and Woodruff Counties. If pumping is specified as zero in Jackson and Woodruff Counties, flow from zone 1 to zone 2 increases by 8 and 14 percent in 2010 and 2050. Flow out of zone 2 occurs mostly from pumping from wells, which ranges from 95 to 96 percent. An increase in pumping by 17 percent from wells in 2050 occurs if pumping from Jackson and Woodruff Counties is specified as zero. Because fewer cells go dry by 2050 , an increase in pumping is possible because more model cells remain active.

Flow into zone 3 is largely from areally distributed recharge and ranges from 61 to 62 percent (table 3 ). Flow into zone 3 from rivers ranges from 24 to 29 percent depending on the simulation period and specification of pumping rates. Minor flow into zone 3 occurs from general and constant-head boundaries in 2010 and 2050. Flow out of zone 3 through discharge to rivers ranges from 20 to 21 percent of the total flow. Pumping by wells represents 78 and 79 percent of flow out of the zone in 2010 and 2050. Specification of a pumping rate of zero in Jackson and Woodruff Counties (zone 1) results in negligible changes in the flow components within zone 3 , largely because Crowleys Ridge acts as a barrier to flow between these zones.

Flow into zone 4 is largely from areally distributed recharge, which ranges from 70 to 78 percent of the total flow into the zone from 2010 to 2050 (table 4). Recharge from rivers represents the next largest flow into zone 4 and ranges from 8 to 14 percent of the total flow into zone 4 . In predevelopment (not shown in table 4), 96 percent of the flow out of zone 4 results from discharge to rivers, whereas that number reduces to 6 percent when pumping from wells occurs, which represents 92 percent of the total flow out of zone 4 . Specification of a pumping rate of zero in Jackson and Woodruff Counties has negligible effect on flow components in zone 4 .

Another comparison of the effect of varying pumping rates in the model on flow components within model zones was made by specifying a 50 -percent reduction in pumping in Jackson and Woodruff Counties (scenario 3 ) beginning in 1998 until 2050, and comparing the flow budget terms from 


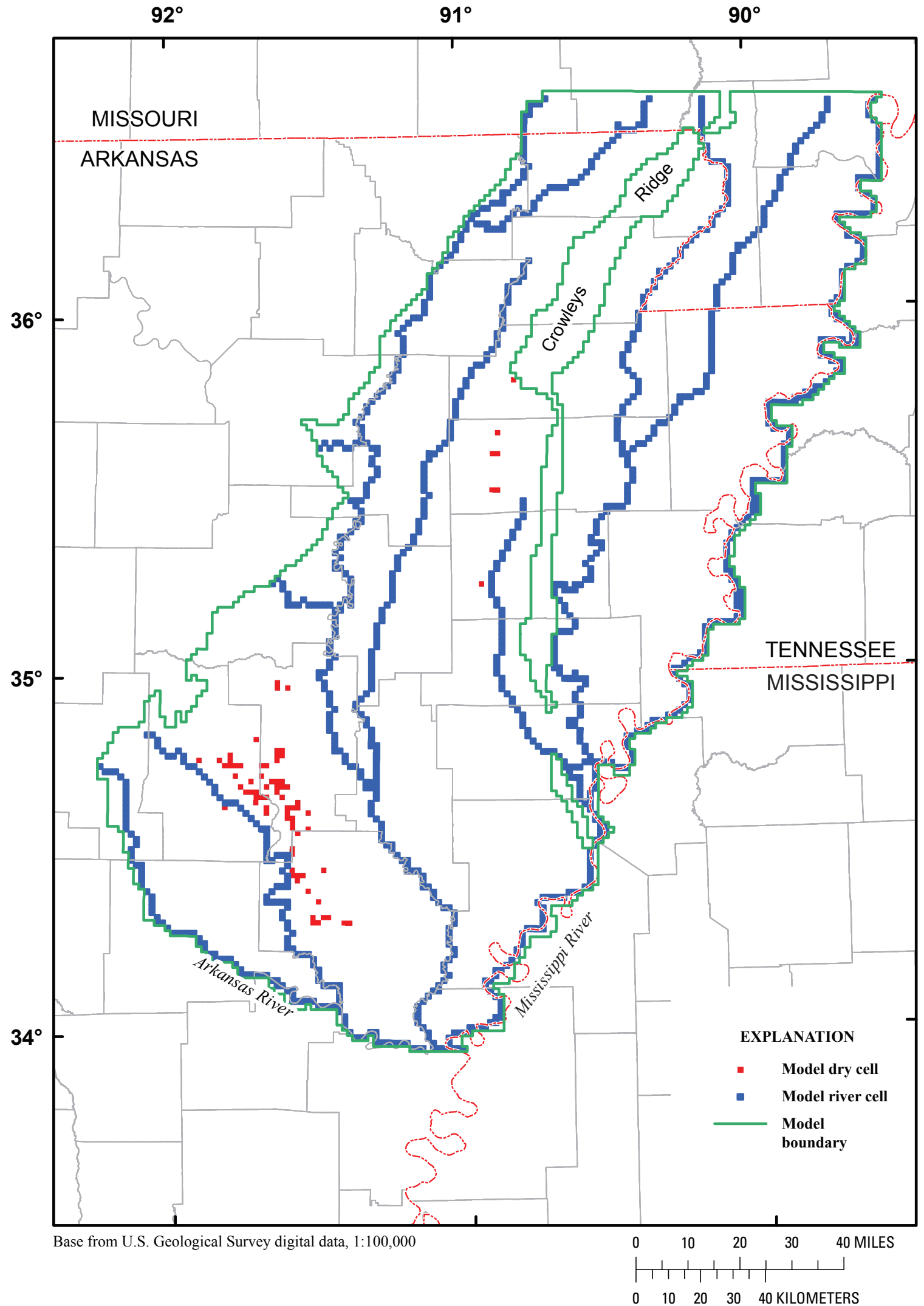

Figure 11. Dry cell occurrences in 2010, scenario 1. 


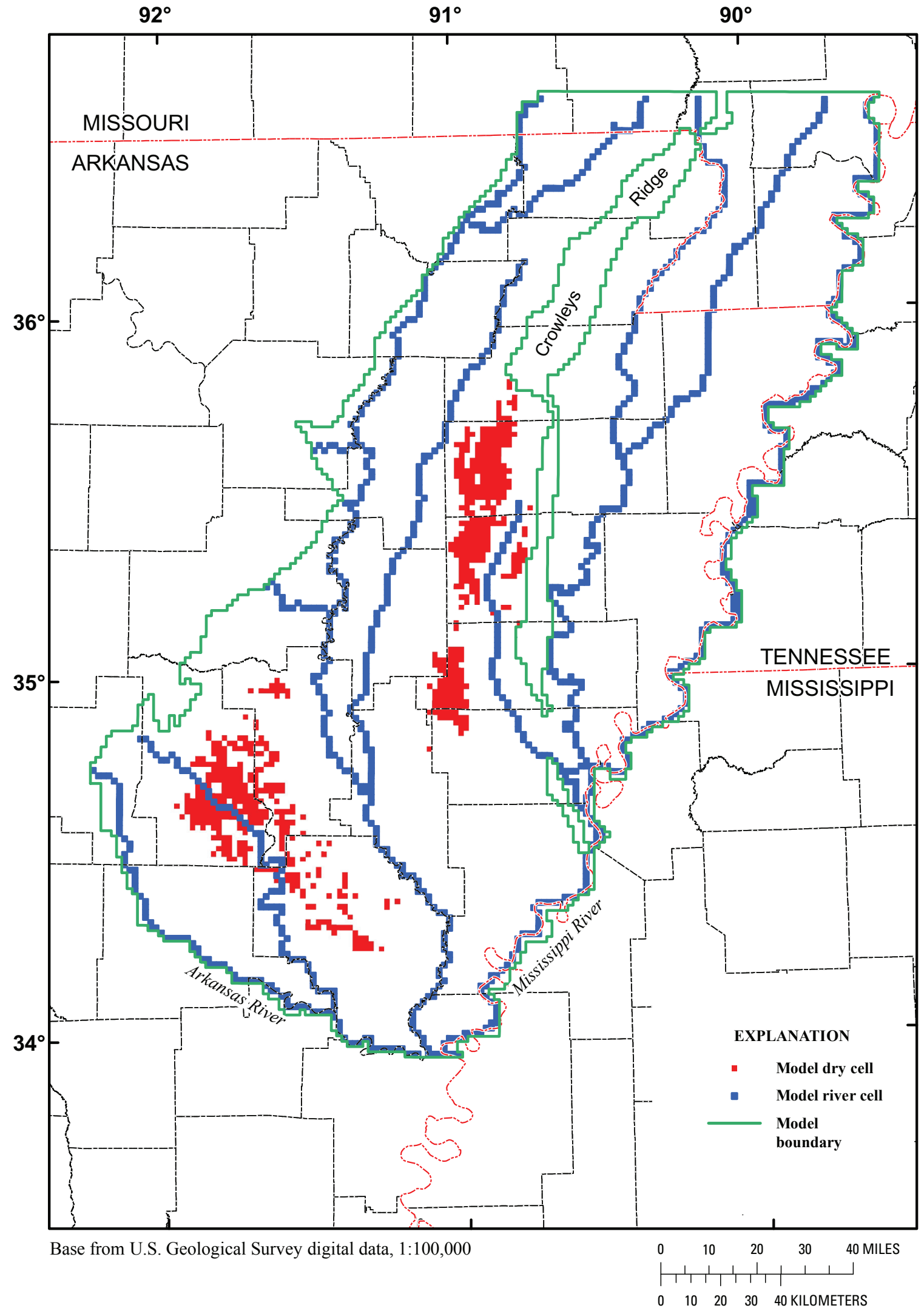

Figure 12. Dry cell occurrences in 2050, scenario 1. 


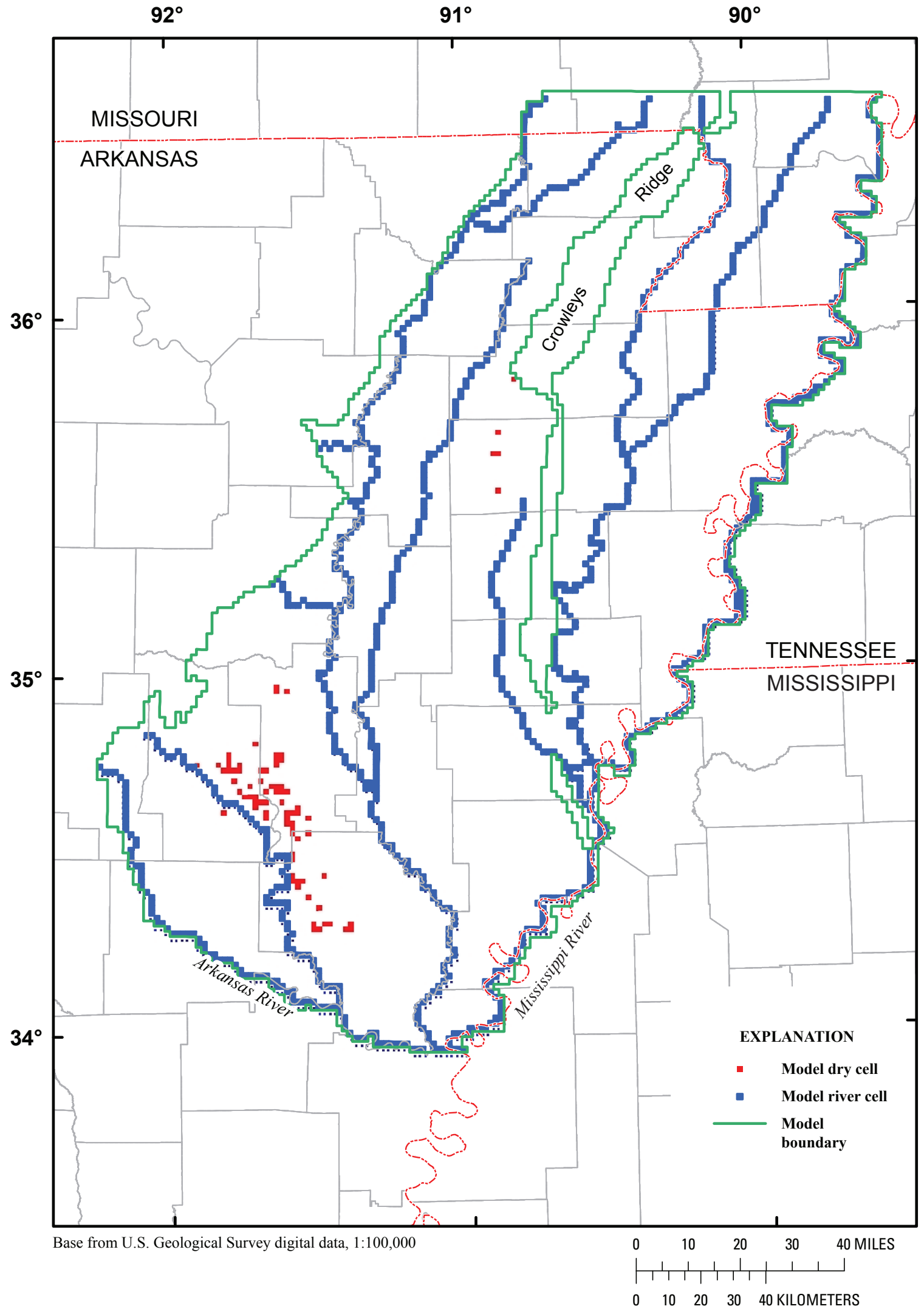

Figure 13. Dry cell occurrences in 2010, scenario 2. 


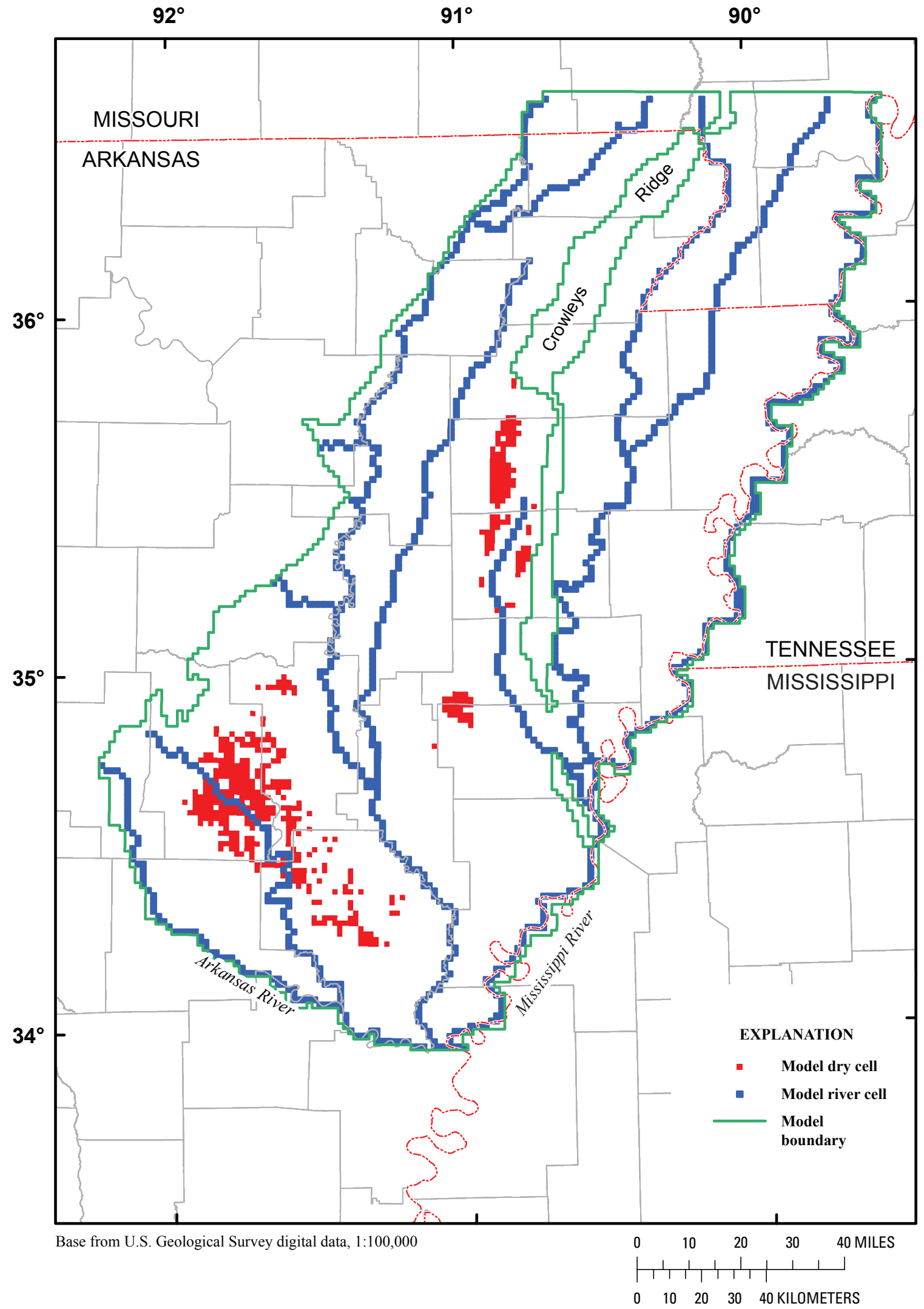

Figure 14. Dry cell occurrences in 2050, scenario 2. 


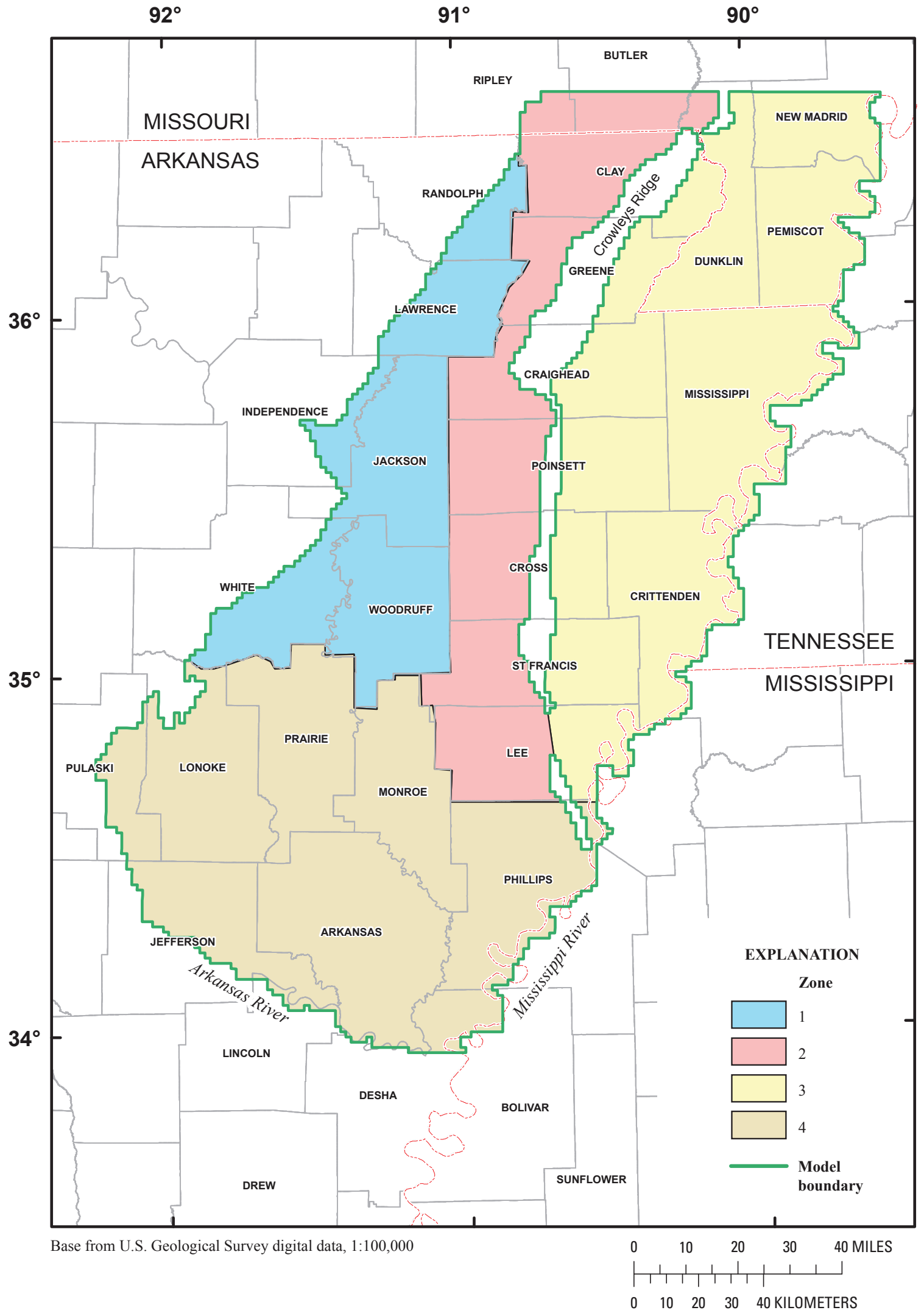

Figure 15. Model area divided into four zones used in zone-budget analysis. 
that simulation with those from the simulation without this reduction in pumping (scenario 1). Tables 5 through 8 show the flow budget terms for zones 1 through 4 shown in figure 15. In zone 1 (table 5 ) discharge to rivers increases by 7 and 9 percent in 2010 and 2050 if the reduction in pumping is applied. Flow from zone 1 into zone 2 increased by 5 and 8 percent in 2010 and 2050. Pumping from wells in the zone was reduced 25 percent. In zone 2 (table 6 ), the major changes that occur are an increase in the amount of pumping from wells (10 percent in 2050) and flow in from zone 1 ( 8 percent in 2050). In zones 3 and 4 (tables 7 and 8), changes in flow components were minor when a 50-percent reduction in pumping in Jackson and Woodruff Counties was specified.

\section{Effects of Pumping on Water Levels}

To show the effect that changes in pumping rates have on simulated water levels, difference maps were prepared using results from each of the three scenarios. The difference in simulated water levels between scenario 1 and scenario 2 in 2050 over the entire model area is shown in figure 16. The largest difference in water levels occurs as an increase between 60 to $80 \mathrm{ft}$, mostly over Jackson and Woodruff Counties, but also over parts of western Cross and Poinsett Counties. When pumping in Jackson and Woodruff Counties is reduced to half the original amount (scenario 3 ), the difference with that of scenario 1 is between 20 to $40 \mathrm{ft}$ in Jackson and Woodruff Counties (fig. 17). The difference between scenarios 2 and 3 is shown in figure 18, with the majority of the difference occurring as a rise between 20 and $40 \mathrm{ft}$ occurring mostly in Jackson and Woodruff Counties and the western parts of Cross and Poinsett Counties.

\section{Model Limitations}

Simulated water levels within the model represent average conditions over the one-square-mile grid cells of the model. Because the model is a simplification of a complex system, some error in simulated water levels is expected, similar to the mean absolute difference between observed and simulated water levels of about $5 \mathrm{ft}$ obtained by Gillip and Czarnecki (2009). Local variations in hydraulic conductivity and specific storage not accounted for in the model result in additional differences between simulated and actual water level. Hypothetical scenarios involving reductions in pumping in Jackson and Woodruff Counties are not intended to imply that such reductions are likely or even possible. The reductions were simulated merely to evaluate the effect that those reductions in pumping had on other parts of the flow system.

\section{Summary}

The Mississippi River Valley alluvial aquifer is a waterbearing assemblage of gravels and sands that underlies about 32,000 square miles of Arkansas, Kentucky, Louisiana, Mississippi, Missouri, and Tennessee. In Arkansas, the alluvial aquifer occurs in an area generally ranging from 50 to 125 miles in eastern to western extent and about 250 miles north to south, adjacent to the Mississippi River. Pumping of groundwater from the alluvial aquifer for agriculture started in the early 1900s in the Grand Prairie area for the irrigation of rice and soybeans. From 1965 to 2005, water use in the alluvial aquifer increased 655 percent. In 2005, 6,242 million gallons per day of water were pumped from the aquifer, primarily for irrigation and fish farming. Water-level declines in the alluvial aquifer were documented as early as 1927. Long-term waterlevel measurements in the alluvial aquifer show an average annual decline of 1 foot per year in some areas.

A MODFLOW digital groundwater-flow model of the alluvial aquifer of northeastern Arkansas published in 2003 was developed to assist groundwater managers with assessing the impact of future stresses on the groundwater-flow system induced by groundwater pumping. The model was updated in 2009 to include water-use and water-level data from 1998 to 2005 as part of model validation. The utility of the updated model was extended by performing groundwater-flow assessments of the alluvial aquifer at specific areas of interest using a variety of methods. One such area is along the western side of Crowleys Ridge, which includes western parts of Clay, Greene, Craighead, Poinsett, Cross, St. Francis, and Lee Counties. This area was designated as the Cache Critical Groundwater Area by the Arkansas Natural Resources Commission in 2009 because groundwater levels have dropped below half the original saturated thickness of the alluvial aquifer. The updated model MODFLOW files were imported into the Groundwater Modeling System (GMS) software package. A comparison of model output between the GMS version and the stand-alone version of MODFLOW was performed by taking the difference in simulated hydraulic head values at various time steps. In general, the comparison was good, as illustrated by the preponderance of difference values grouped between $+/-0.5 \mathrm{ft}$.

Three scenarios were simulated, in part, to allow assessment of the role that pumping in Jackson and Woodruff Counties has on groundwater levels and flow rates into and out of counties located along the western side of Crowleys Ridge. In scenario 1 (the baseline scenario), the 2005 pumping rate is applied from 2005 through 2050 without change. In scenario 2 , pumping is the same as in scenario 1 except that the pump- 


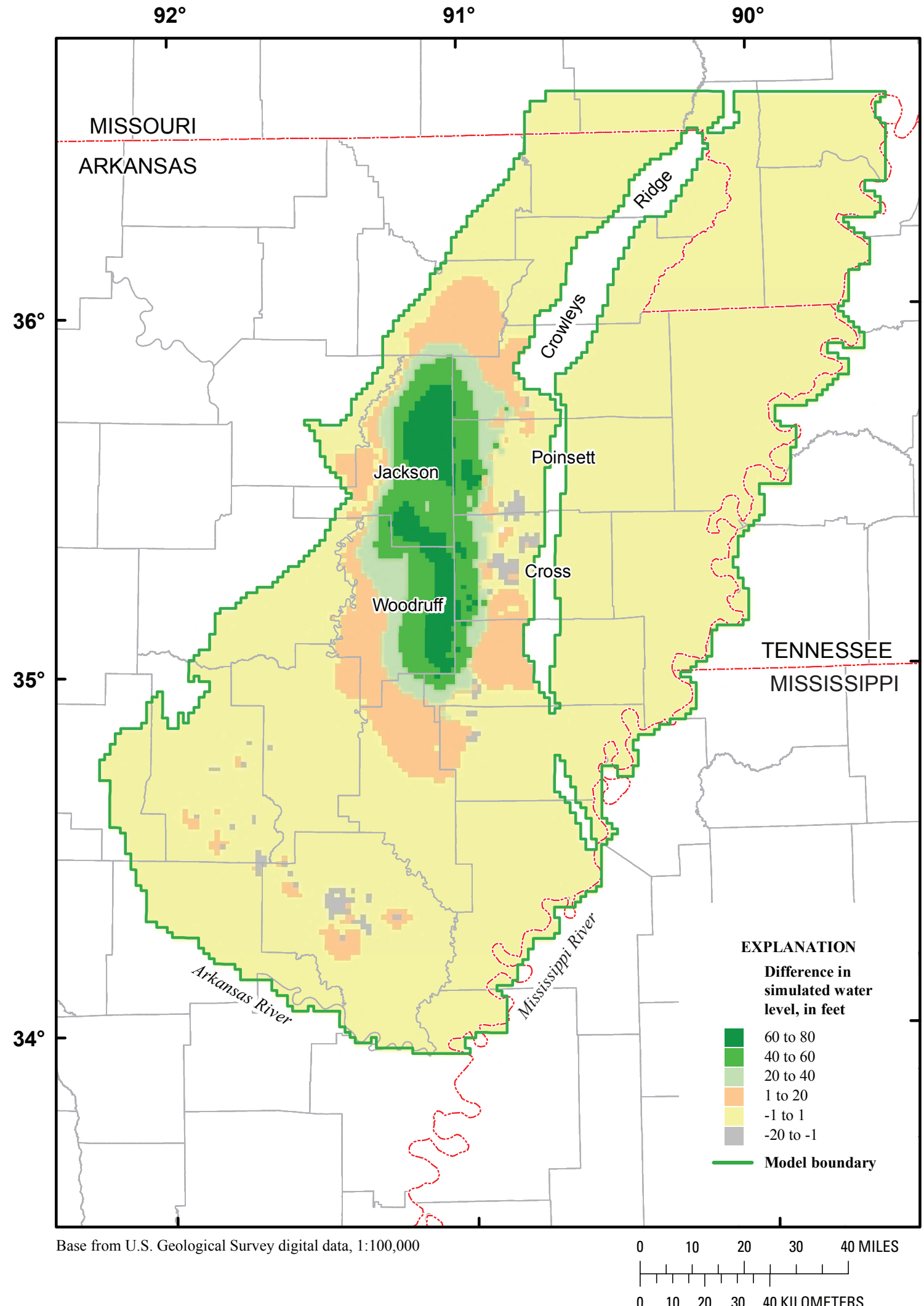

Figure 16. Simulated water levels from scenario 2 (no pumping in Jackson and Woodruff Counties) minus water levels from scenario 1 (full pumping in Jackson and Woodruff Counties). 


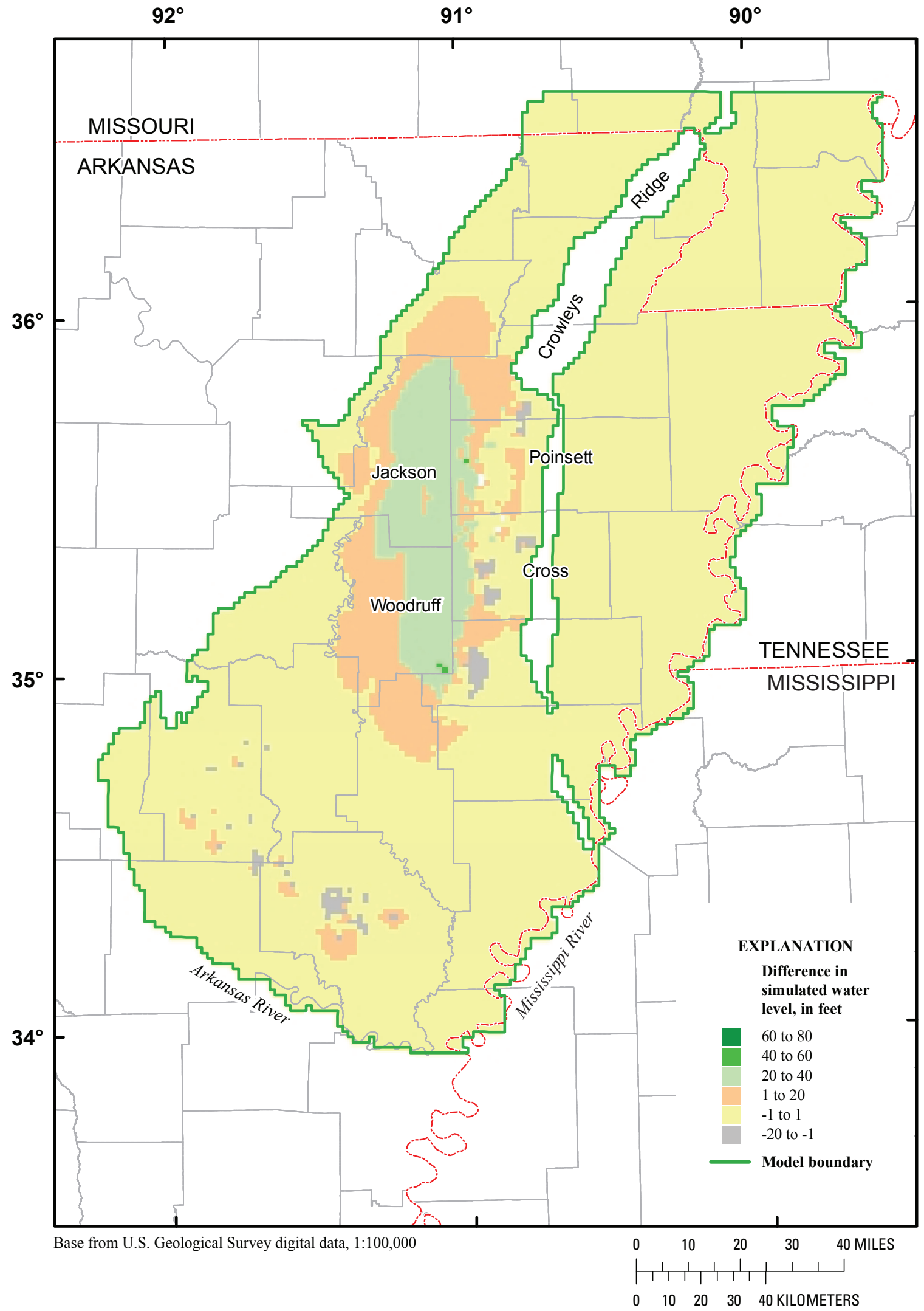

Figure 17. Simulated water levels from scenario 3 (half pumping in Jackson and Woodruff Counties) minus water levels from scenario 1 (full pumping in Jackson and Woodruff Counties). 


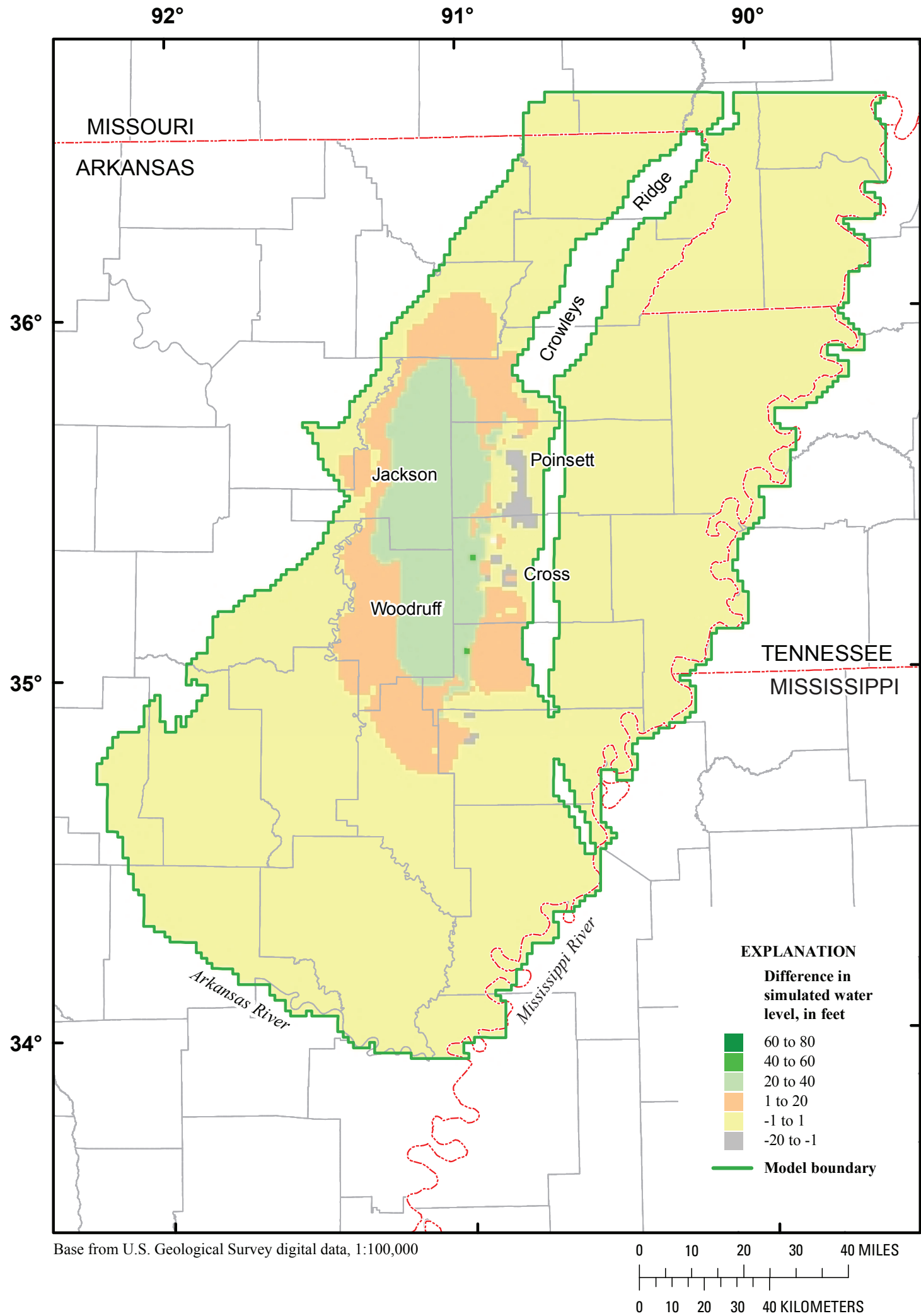

Figure 18. Simulated water levels from scenario 2 (no pumping in Jackson and Woodruff Counties) minus water levels from scenario 3 (half pumping in Jackson and Woodruff Counties). 
ing rate in Jefferson and Woodruff Counties is specified as zero from 1998 to 2050. In scenario 3, pumping is the same as in scenario 1 except that the pumping rate in Jefferson and Woodruff Counties is specified as half the rate specified for stress periods from 1998 to 2050.

Particle tracking using MODPATH was done to assess the direction and distance of travel that particles take from specific model locations. Factors that affect the distance particles will travel include: (1) pumping rates in the vicinity of particles, (2) when and if cells with specified pumping go dry, and (3) changes in pumping rates during the simulation period. Particles can travel further if cells do not go dry, because pumping can continue in them even if the total pumping rate from the model may be less. Particles introduced in Jackson and Woodruff Counties travel further for scenario 2 than for scenario 1 .

Flow-vectors were generated using the built-in graphics capability in GMS. Groundwater-flow vectors depict magnitude and direction of simulated groundwater flow. Groundwater-flow magnitude is the product of the hydraulic gradient and hydraulic conductivity. Because only two values of hydraulic conductivity (230 and 730 feet per day) are specified over the model domain, variability in groundwater-flow magnitude is caused largely by variation in hydraulic gradient. Groundwater-flow vectors and hydraulic-head maps for scenarios 1 and 2 for 2010 and 2050 were generated to allow for a comparison of groundwater-flow magnitude and direction. The lengths of the vectors presented represent the horizontal magnitude of flow, and the orientation of each vector indicates the horizontal direction of flow.

The occurrence of dry cells was analyzed and observed to vary between model stress periods and scenarios. For scenario 1,78 dry cells occur at the beginning of 2010 compared to 671 at the beginning of 2050. When pumping in Jackson and Woodruff Counties is specified as zero (an overall reduction in pumping of about 10 percent) (scenario 2), 78 dry cells occur at the beginning of 2010 and 476 at the beginning of 2050 (a reduction in dry cells of 29 percent).

Zone-budget analyses using ZONEBUDGET were performed to assess the rate of water entering and leaving specified zones within the model. Zone-budget analysis was performed on the simulated groundwater flow by dividing the model into four separate zones and calculating the individual flow components for each zone at different simulation times for the three pumping scenarios. Reduction of pumping in scenarios 2 and 3 resulted in substantially more groundwater flow into the Cache Critical Groundwater Area and more flow to rivers within the model area.

To show the effect that changes in pumping rates have on simulated water levels, difference maps were prepared using results from each of the three scenarios. The largest difference in water levels occurs as an increase between 60 to 80 $\mathrm{ft}$, mostly over Jackson and Woodruff Counties, but also over parts of western Cross and Poinsett Counties. When pumping in Jackson and Woodruff Counties is reduced to half the original amount (scenario 3), the difference with that of scenario 1 is between 20 to $40 \mathrm{ft}$ in Jackson and Woodruff Counties. The difference between scenarios 2 and 3 occurs as a rise between 20 and $40 \mathrm{ft}$ mostly in Jackson and Woodruff Counties and the western parts of Cross and Poinsett Counties.

\section{References Cited}

Aquaveo, 2009, Water Modeling Solutions available on the World Wide Web, accessed September 1, 2009, at http:// www.aquaveo.com/gms

Arkansas Natural Resources Commission, 2009, Cache Critical Ground Water Area available on the World Wide Web, accessed December 9, 2009, at http://www.anrc.arkansas. gov/Cache\%20Critical_Area\%2012-09-09.pdf

Engler, Kyle, Thompson, D.G., and Kazmann, R.G., 1945, Ground-water supplies for rice irrigation in the Grand Prairie region, Arkansas: University of Arkansas, Agriculture Experiment Station Bulletin No. 457, 56 p.

Gillip, J.A., and Czarnecki, J.B., 2009, Validation of a ground-water flow model of the Mississippi River Valley alluvial aquifer using water-level and water-use data for 1998-2005 and evaluation of water-use scenarios: U.S. Geological Survey Scientific Investigations Report 20095040, $22 \mathrm{p}$.

Harbaugh, A.W., 1990, A computer program for calculating subregional water budgets using results from the U.S. Geological Survey Modular Three-Dimensional Finite-Difference Ground-Water Flow Model: U.S. Geological Survey Open-File Report 90-392, 24 p.

Holland, T.W., 2007, Water use in Arkansas, 2005: U.S. Geological Survey Scientific Investigations Report 2007-5241, $33 \mathrm{p}$.

Pollock, D.W., 1994, User's guide for MODPATH/MODPATH-PLOT, Version 3; a particle tracking post-processing package for MODFLOW, the U.S. Geological Survey finite-difference ground-water flow model: U.S. Geological Survey Open-File Report 94-464, 249 p.

Reed, T.B., 2003, Recalibration of a ground-water flow model of the Mississippi River Valley alluvial aquifer of northeastern Arkansas, 1918-1998, with simulations of water levels caused by projected ground-water withdrawals through 2049: U.S. Geological Survey Water-Resources Investigations Report 03-4109, 58 p.

Schrader, T.P., 2006, Status of water levels and selected waterquality conditions in the Mississippi River Valley alluvial aquifer in eastern Arkansas, 2004: U.S. Geological Survey Scientific Investigations Report 2006-5128, 82 p. 
Tables 1-8 


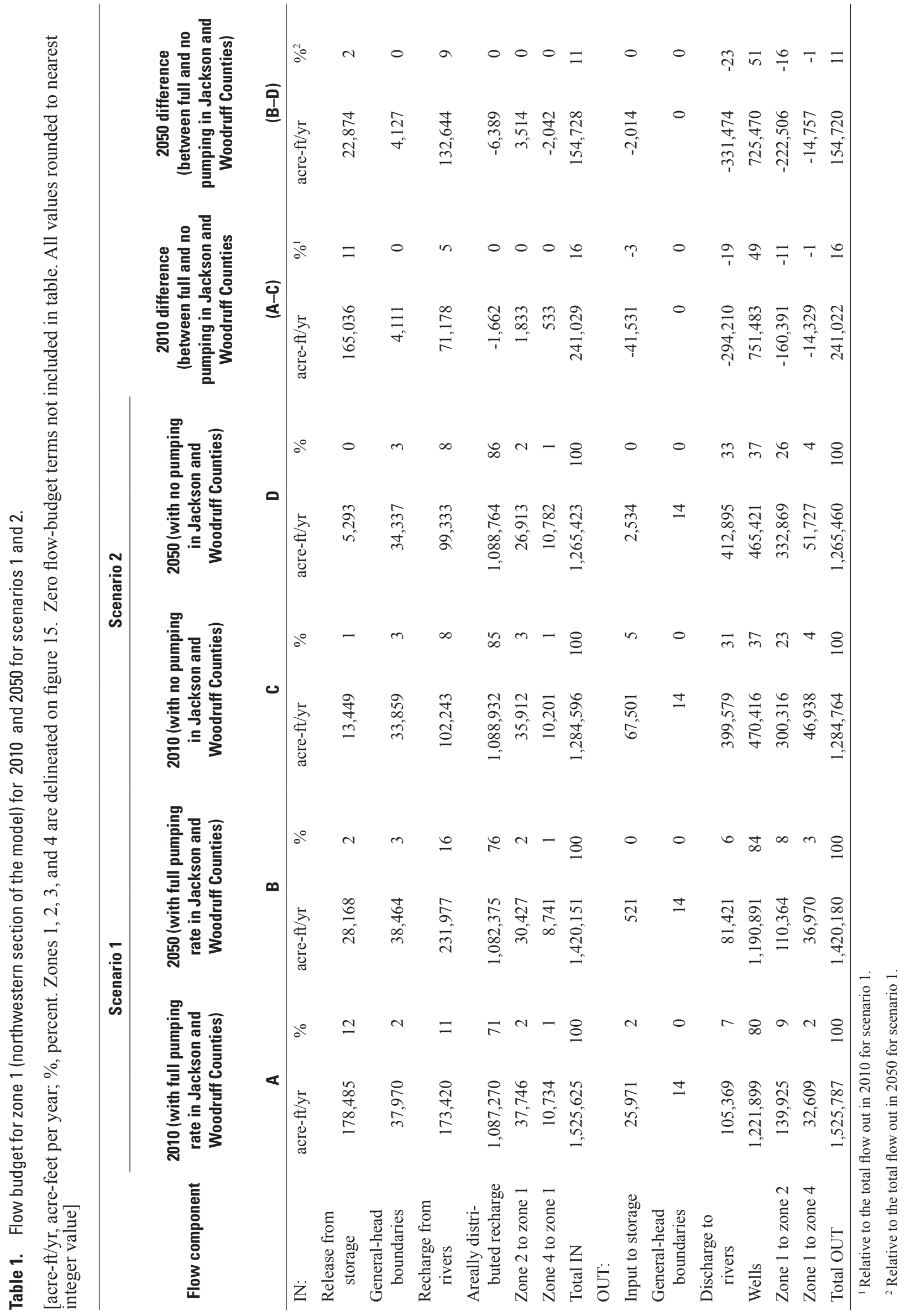




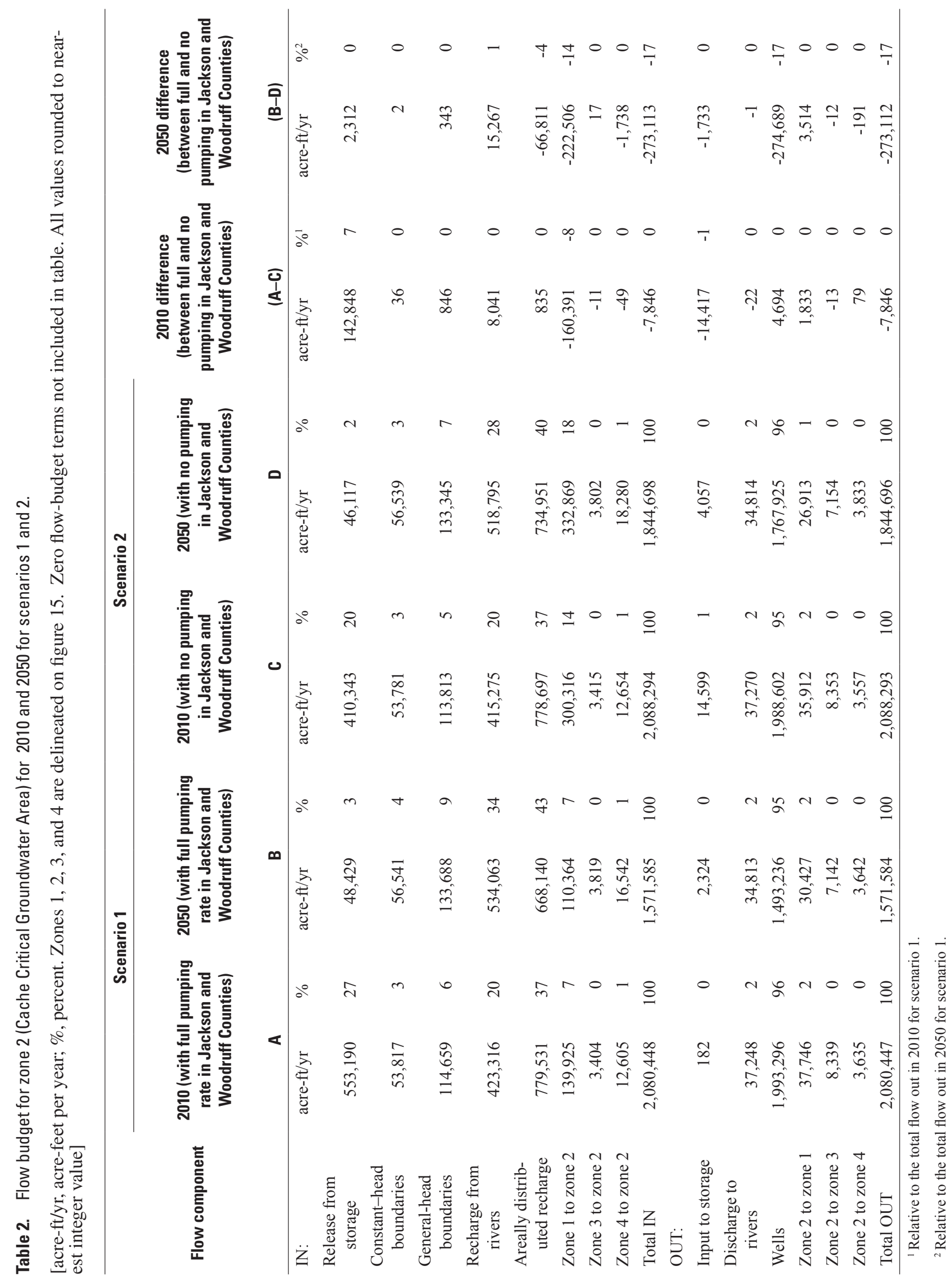




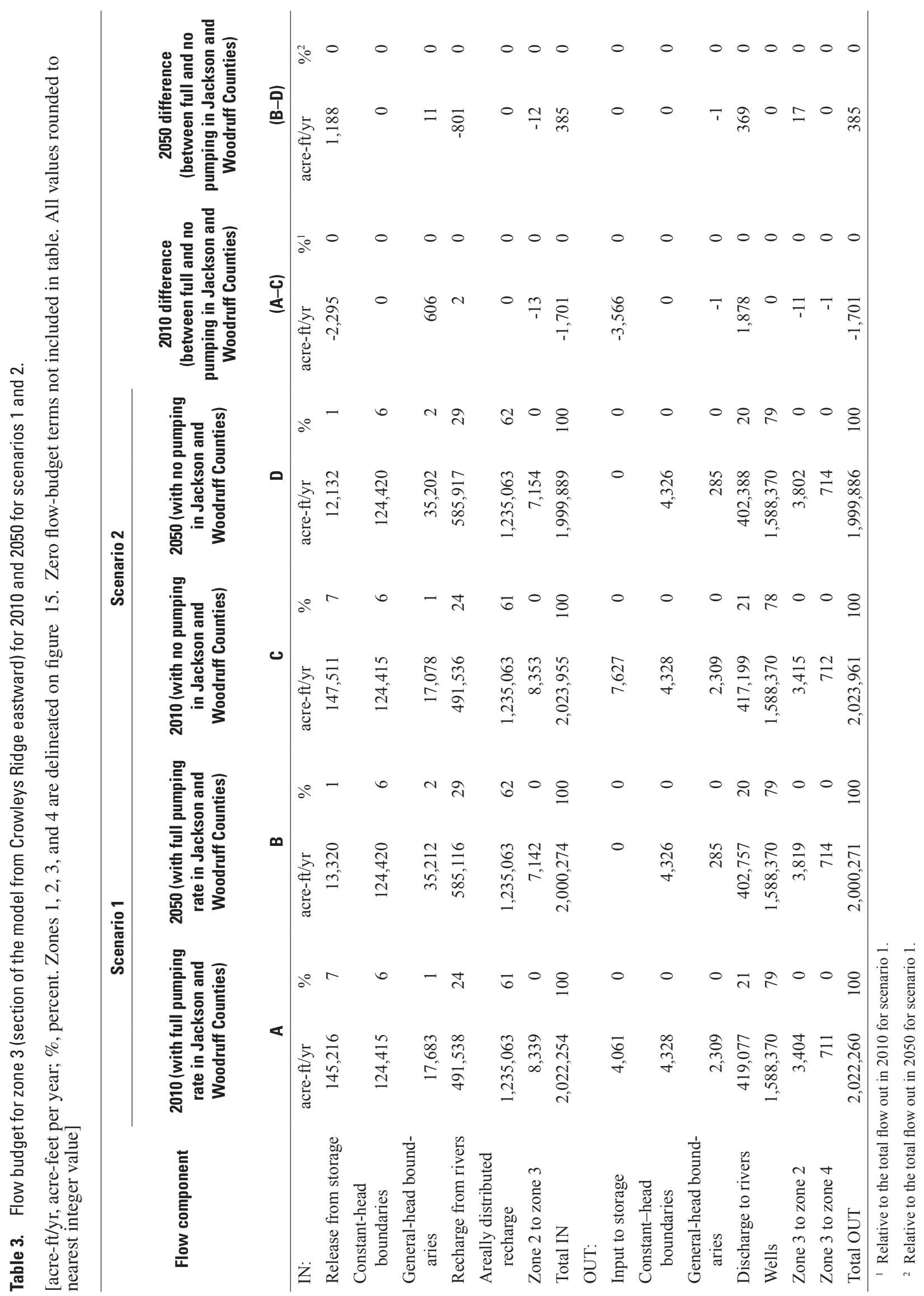




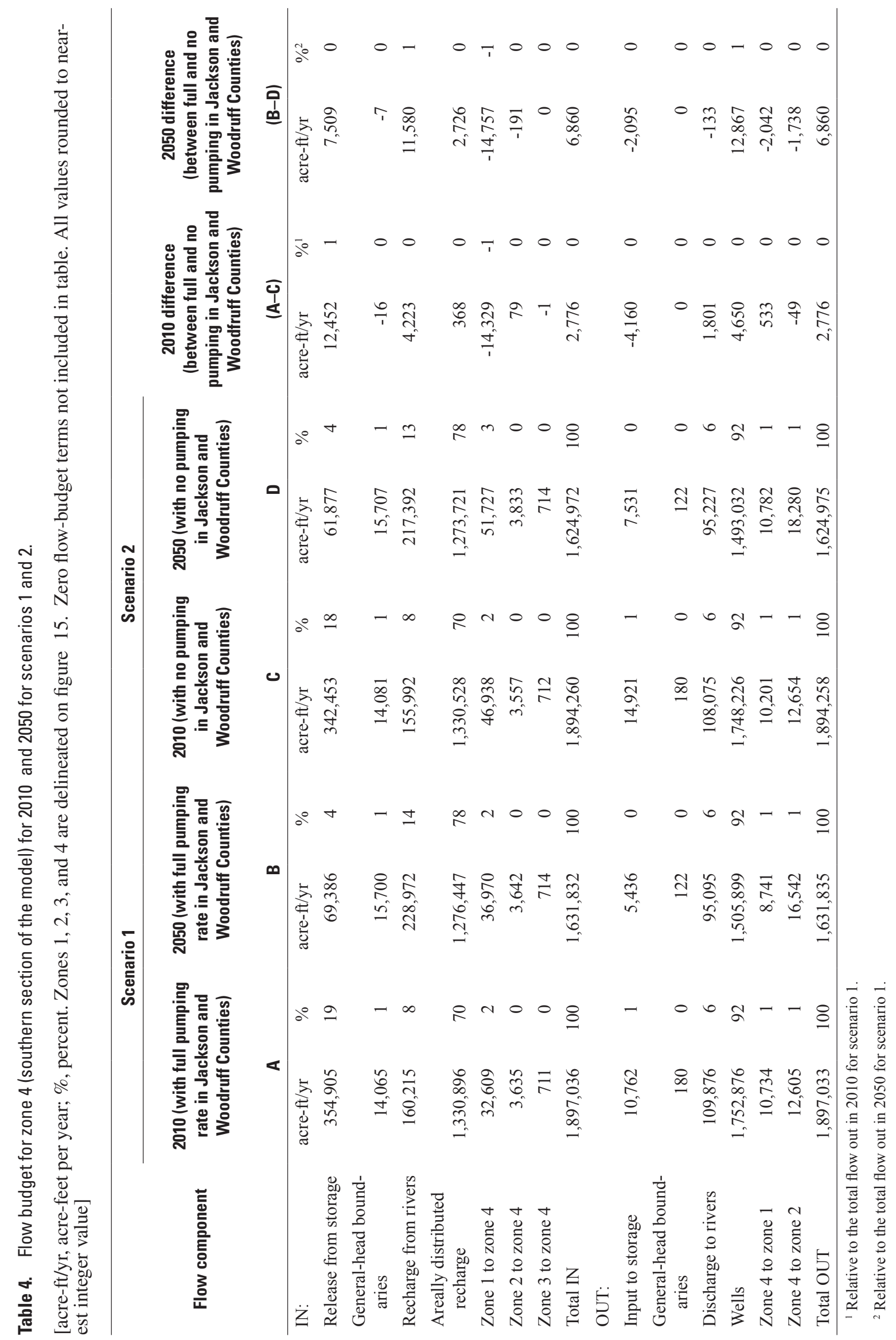




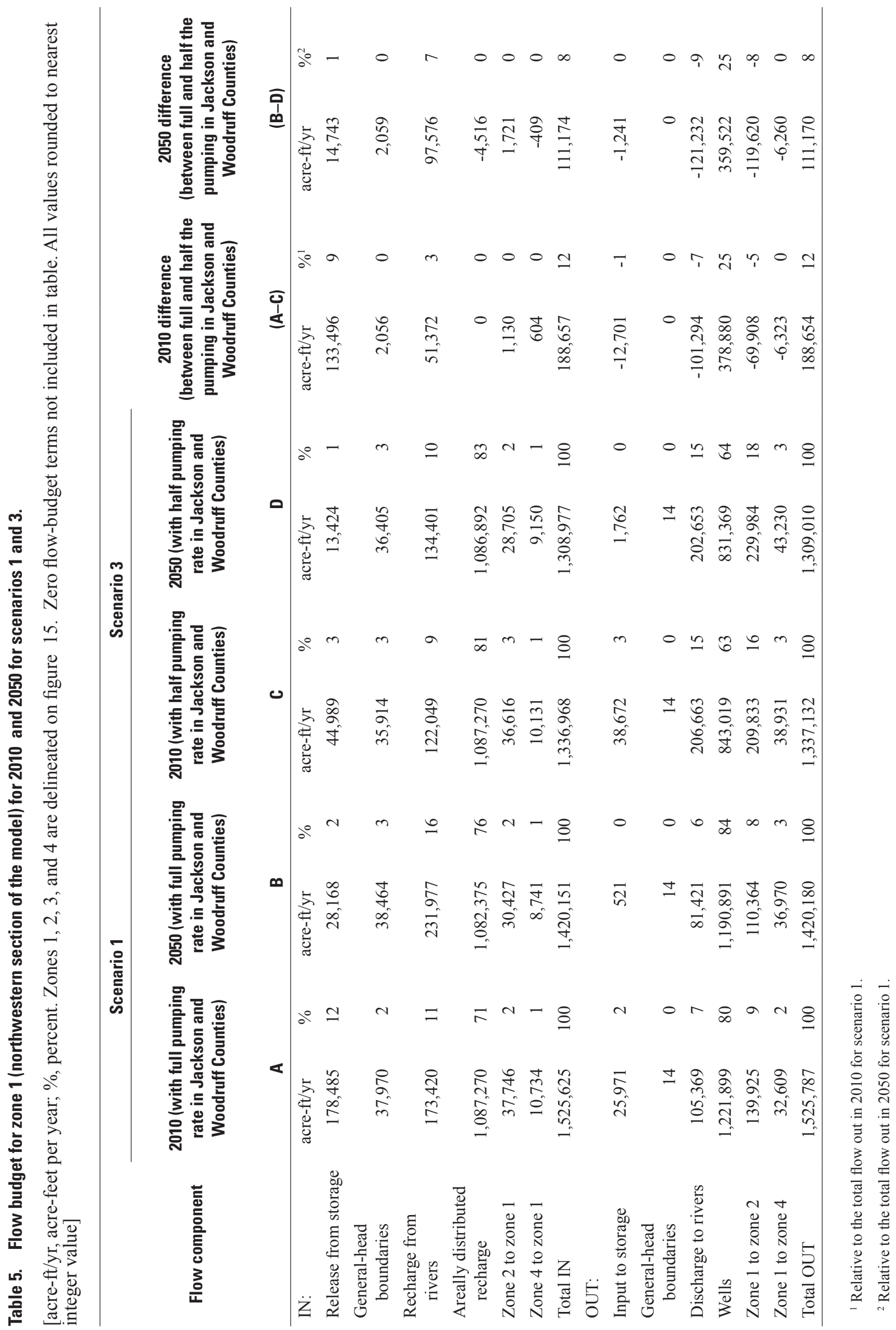




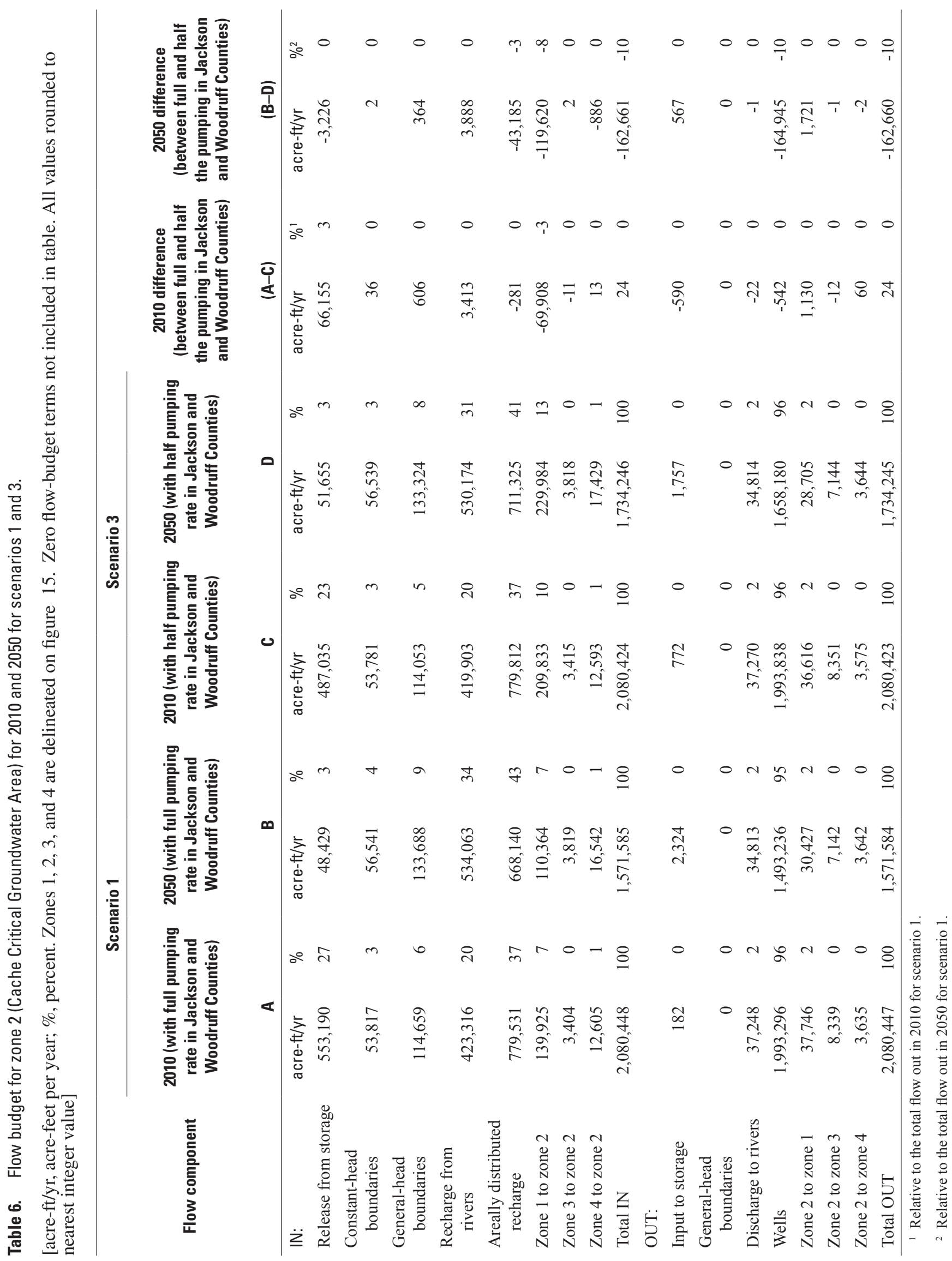




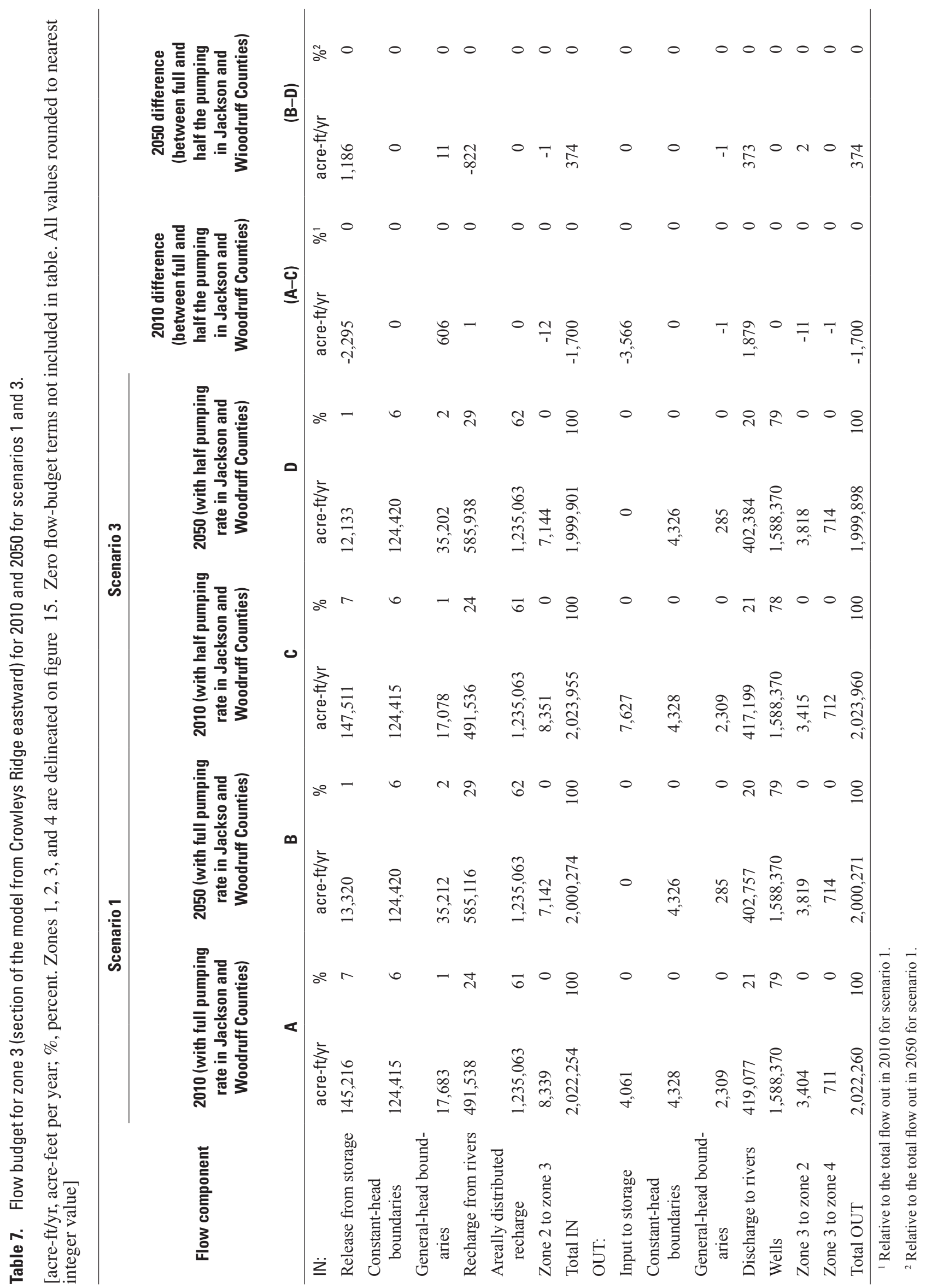




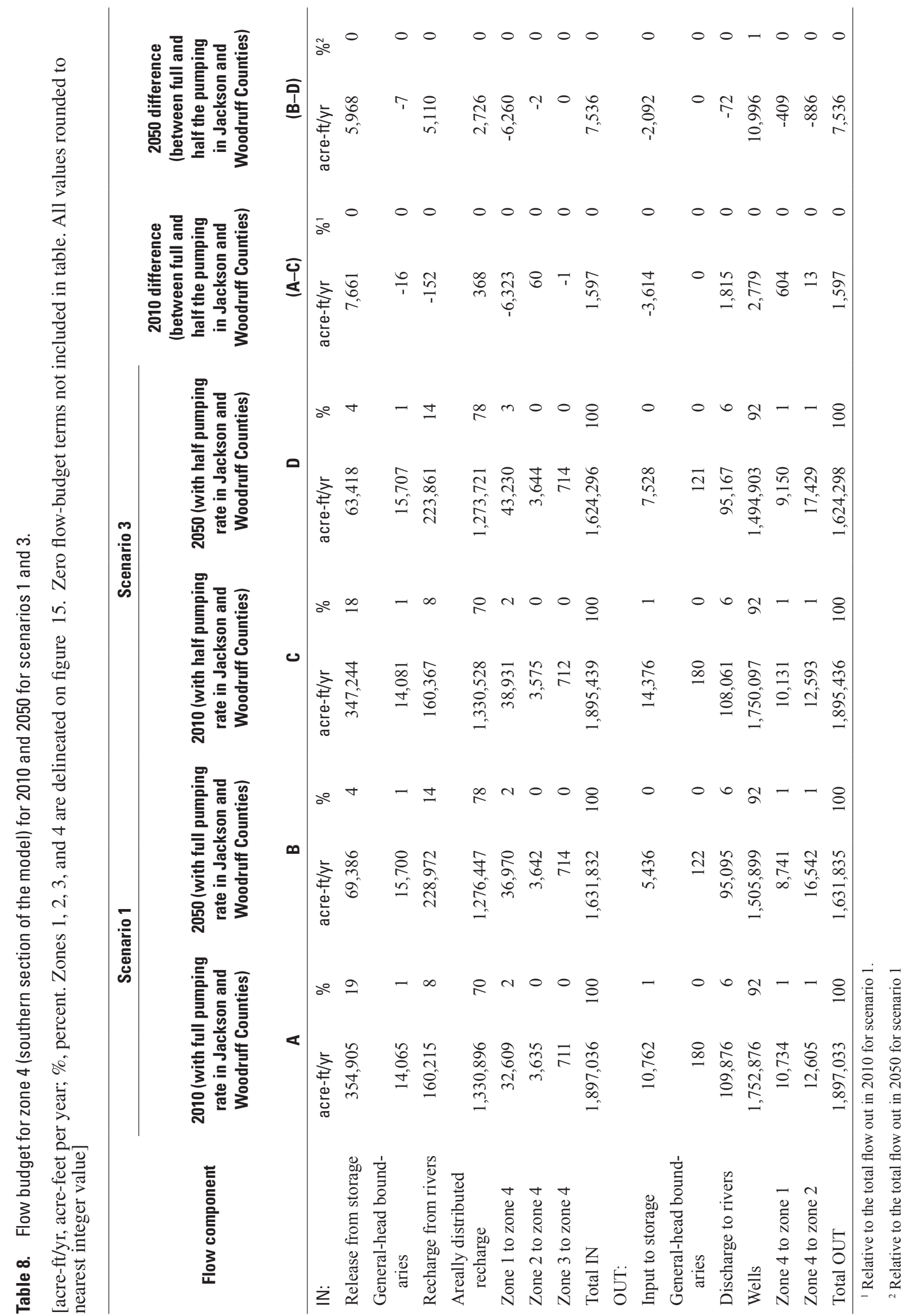


Publishing support provided by: Lafayette Publishing Service Center

For more information concerning the research described in the report

U.S. Geological Survey Arkansas Water Science Center

401 Hardin Road

Little Rock, AR 72211-3528

(501) 228-3600

http://ar.water.usgs.gov 
